

\section{Atuação Anticíclica dos Bancos Públicos Brasileiros}

\section{Countercyclical role of Public Brazilian Banks}

* Fernando Nogueira da Costa

\section{Resumo}

Neste artigo, testa-se a hipótese de que os verdadeiros fazedores do mercado de crédito bancário, para o período recente, foram os bancos públicos. Inicia-se com uma comparação das atuações desses bancos antes e depois de 2003, quando assumiu um governo socialdesenvolvimentista no Brasil. Em seguida, focaliza-se a atuação social-desenvolvimentista do BNDES e, depois, o Programa de Financiamento Habitacional da Caixa Econômica Federal. Examina se a atuação anticíclica dos bancos públicos resultou em um crowding out creditício. Após comparar algumas características do sistema bancário brasileiro com as dos bancos de outros países emergentes, apresenta-se o modus operandi e as perspectivas futuras dos negócios bancários na economia brasileira. Encerra-se com uma breve conclusão que lista as principais virtudes e os eventuais defeitos dos bancos públicos brasileiros. Sugere uma possível solução para o problema de interferência política em suas direções.

Palavras-chave: bancos - financiamento do desenvolvimento

\begin{abstract}
In this article, we test the hypothesis that the true market makers of the bank credit market, for the recent period, were public banks. It begins with a comparison of the performances of these banks before and after 2003, when he took a socialdevelopmentalist government in Brazil. Then focuses on the social-developmental role of the BNDES and then the Housing Finance Program of the Caixa Econômica Federal. Examines whether the countercyclical role of public banks resulted in crowding out credit. After comparing some characteristics of the Brazilian banking system with those of banks in other emerging countries, presents the modus operandi and future prospects of the banking business in the Brazilian economy. Ends with a brief conclusion that lists the main virtues and possible shortcomings of Brazilian public banks. It suggests a possible solution to the problem of political interference in their direction.
\end{abstract}

Keywords: Banks - Economic Development: Financial Markets 


\section{Introdução}

Cegundo a argumentação clássica latino-americana, "a experiência parece ensiOnar que, exceto quando são expressamente criadas instituições financeiras 'desenvolvimentistas' sob controle do setor público, dificilmente um país pode resolver os problemas de transferência espacial ou intersetorial de recursos, para regiões ou setores mais atrasados (ou para novos setores), através do desenvolvimento espontâneo de seus intermediários financeiros". Em síntese, os bancos públicos existem para corrigir as falhas do mercado.

A concessão de crédito por parte de bancos privados rege-se, evidentemente, por considerações de rentabilidade, liquidez e risco das aplicações e não por seus fins sociais ou desenvolvimentistas. O acesso ao crédito dos bancos privados é determinado pelas garantias que podem ser oferecidas e juros que podem ser pagos. Isso significa, geralmente, que só são favorecidos os que já estão instalados nos setores de mais alto retorno financeiro e que oferecem, portanto, aplicações seguras.

Não seria de esperar que coubesse a uma Instituição Financeira Privada a responsabilidade de:

1. corrigir determinado padrão de desenvolvimento,

2. modificar a distribuição dos recursos, em outra direção setorial, e

3. fomentar a elevação da taxa de investimento contra-ciclo.

Caberia à Instituição de Políticas Públicas, ou seja, àquela que não visasse, primordialmente, a maximização de seu lucro, o papel de contribuir para o fomento do desenvolvimento. Com a funcionalidade 'desenvolvimentista', os bancos públicos assumiriam papel ativo (não neutro) na distribuição de recursos, sendo direcionados para fins qualificados como prioritários pela política pública. Esses fins sociais e econômicos serão diferentes daqueles que se regem por critérios da rentabilidade privada.

O setor financeiro público compensaria, em parte, a deficiência de atuação social do setor privado na intermediação financeira. Nessa funcionalidade desenvolvimentista, a Instituição de Políticas Públicas eleva o fluxo de recursos oriundos de fundos sociais, direcionando-os para setores necessitados como a agricultura familiar, a habitação popular, pequenas e médias empresas, etc., desconcentrando a distribuição de fundos em relação aos grandes clientes. Pode também priorizar certas atividades, para o alcance de metas de política econômica, por exemplo, o fomento à exportação.

O surgimento da atuação financeira do Estado desenvolvimentista ocorreu, no Brasil, quando ele se deparou com a inexistência de adequada infraestrutura socioeconômica e a carência de empreendedores dinâmicos nas atividades industriais. Isso acontecia devido à mentalidade empresarial então conservadora e avessa ao risco.

As instituições financeiras públicas federais no Brasil são market makers, isto é, 'fazedoras do mercado de crédito'. Há hierarquia entre os agentes financeiros. Os market makers são os agentes líderes, com fontes de financiamento em fundos sociais, 
que determinam as taxas de juros de referência para empréstimos. Os líderes têm maior capacidade de delinear as tendências do mercado.

Minha hipótese é que os verdadeiros 'fazedores do mercado', na economia brasileira, são os bancos públicos, cujos comportamentos regulam a competição no segmento. São, entre os bancos comerciais, o Banco do Brasil (BB) e a Caixa (CEF), sendo a atuação desta de especial importância no financiamento imobiliário e daquele no financiamento agrícola. No crédito à infraestrutura e aos insumos básicos, o Banco Nacional de Desenvolvimento Econômico e Social (BNDES) esteve sempre praticamente sozinho. No financiamento ao desenvolvimento de regiões periféricas, o Banco da Amazônia (BASA) e o Banco do Nordeste do Brasil (BNB) cumprem um papel indispensável.

Vamos testar essa hipótese para o período recente, iniciando com uma comparação das atuações dos bancos públicos antes e depois de 2003, quando assumiu um governo social-desenvolvimentista no Brasil. Em seguida, dadas suas importâncias, focalizaremos a atuação recente do BNDES e, depois, o Programa de Financiamento Habitacional Minha Casa, Minha Vida. Examinaremos se essa atuação anticíclica dos bancos públicos resultou em um crowding out creditício. Após comparar algumas características do sistema bancário brasileiro com as dos bancos de outros países emergentes, apresentaremos o modus operandi e as perspectivas futuras dos negócios bancários na economia brasileira. Encerraremos com uma breve conclusão, listando as principais virtudes e os contumazes defeitos dos bancos públicos brasileiros. Sugeriremos, enfim, uma possível solução para o problema de interferência política em suas direções.

\section{Bancos Públicos: Antes e Depois de 2003}

Questionava-se, antes de 2003, quando assumiu o Governo brasileiro uma coalizão política de característica social-desenvolvimentista, isto é, em busca da construção de um Estado de Bem-Estar Social, se o sistema financeiro nacional poderia cumprir sua função social básica, a de financiar o desenvolvimento socioeconômico brasileiro. Em dezembro de 2002, a relação crédito/PIB era apenas 26,1\% do PIB com saldo de R\$ 389,2 bilhões. O estoque total das operações de crédito do sistema financeiro atingiu $\mathrm{R}$ 3.111 bilhões em julho de 2015. A relação crédito/PIB alcançou 54,5\%, ou seja, mais do que duplicou com PIB maior. Se antes esta relação do Brasil superava apenas as dos países da América Latina, exceto a do Chile, atualmente, supera inclusive a mediana desta relação dos países emergentes do Leste Europeu, que é $45 \%$ do PIB.

Como o sistema financeiro nacional obteve funding para lastrear esse crescimento extraordinário do crédito já que ele era considerado escasso? Para a resposta, cabe partir de uma constatação não muito comum: a relação financiamento total/PIB não era muito baixa. Porém, na era neoliberal, o destino do financiamento dirigia-se, 
predominantemente, para o setor público, dado o seu endividamento dolarizado e pós-fixado, deixando uma falsa impressão sobre a capacidade de captar funding.

Em dezembro de 2002, somando-se a relação dívida mobiliária federal/PIB (60,6\%) com a relação empréstimos bancários/PIB $(26,1 \%)$, a relação do financiamento total com um PIB de R\$ 1.491,2 bilhões atingia 86,7\%. Depois, a dívida mobiliária federal interna, fora do Banco Central do Brasil (BCB), avaliada pela posição de carteira, baixou para 43,4\% do PIB (ou R\$ 2.475,2 bilhões) em julho de 2015. A relação crédito/PIB alcançou 54,5\% do PIB nominal de R\$ 5.708 bilhões que o BCB estimou para esse mês. Portanto, mudou a composição e cresceu o financiamento total, atingindo $97,1 \%$ do PIB, mais de 10 pontos percentuais de um PIB bem maior.

O M4 (total de Haveres Financeiros) representou 92,8\% do PIB. A entrada de capital estrangeiro para cobrir o déficit do balanço de transações correntes acumularam, nos doze meses anteriores, US\$ 89,4 bilhões, equivalente a 4,34\% do PIB. Logo, o funding do financiamento total $(97,1 \%$ do $\mathrm{PIB})$ correspondeu à soma da relação crédito/PIB de $54,5 \%$ com a dívida mobiliária federal interna, fora do Banco Central, avaliada pela posição de carteira, de 43,4\% do PIB, resultando em 97,9\% do PIB.

A conclusão é que não há carência de funding na economia brasileira. Ao contrário do que afirmam os economistas oposicionistas com uma visão pré-keynesiana, a'baixa poupança' (um resíduo na contabilidade nacional) não é obstáculo ao financiamento do crescimento da economia brasileira.

Como se reverteu a queda brutal do crédito ocorrida durante o governo neoliberal anterior? Caiu de 36,6\% do PIB, em janeiro de 1995, para, em dezembro de 2002, atingir a proporção de $26,1 \%$ do PIB. Veja quadro abaixo.

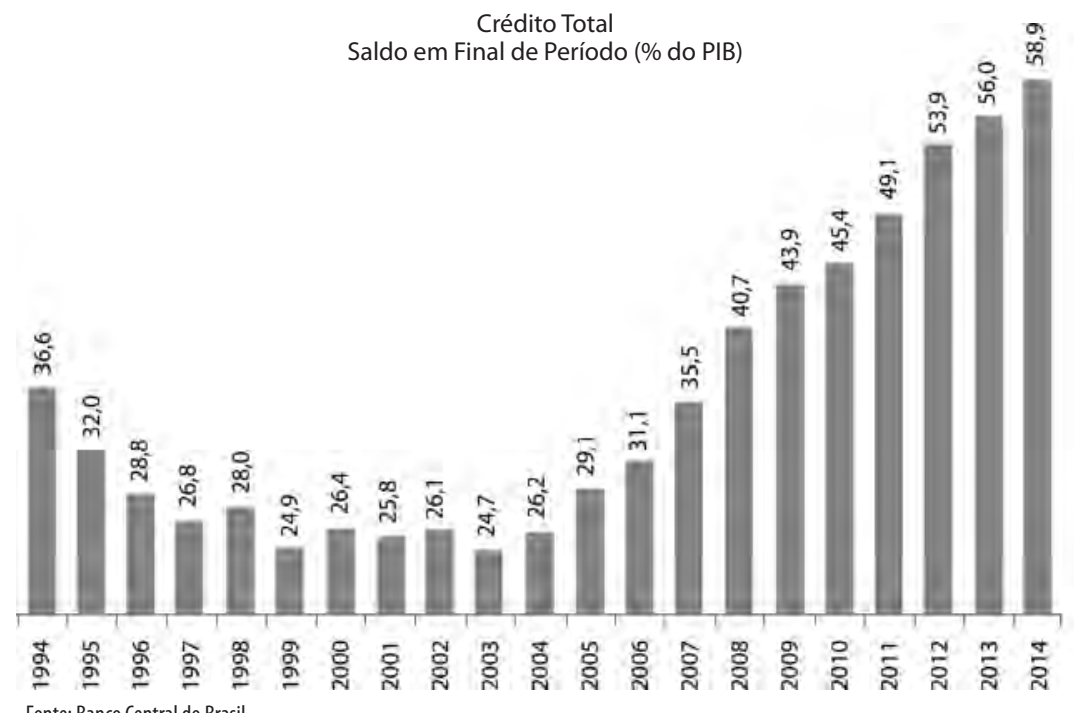


Não é verdade que, depois de 2003, o acesso ao crédito só construiu um 'modelo baseado no consumo pessoal'. A carteira com recursos livres somou R\$ 1.595 bilhões, em julho de 2015, quando o saldo das operações com pessoas físicas de R\$ 794 bilhões, representava a ênfase no crédito consignado (desconto na folha de pagamento inclusive para aposentados) e nas operações com cartão de crédito à vista. Os financiamentos a veículos registraram redução, depois de terem propiciado o mercado brasileiro de venda de veículos tornar-se o quarto maior do mundo. Mas a carteira das pessoas jurídicas totalizou R\$ 801 bilhões, destacando-se as retrações em capital de giro e desconto de duplicatas. Constata-se que Pessoa Física e Pessoa Jurídica dividiram, igualmente, o crédito com recursos livres.

O crédito com recursos direcionados, que oferece taxas de juros reguladas abaixo das atingidas com recursos livres, atingiu $\mathrm{R} \$ 1.516$ bilhões em julho de 2015, praticamente a metade do crédito total. No segmento de famílias, o saldo aumentou para R\$ 675 bilhões, com destaque para o crédito imobiliário. Nas contratações das empresas, o saldo alcançou R\$ 841 bilhões, influenciado, em parte, pelo efeito da variação cambial nos financiamentos para investimentos do BNDES.

De acordo com o balanço de junho de 2014, já foram contratadas 3,408 milhões de unidades habitacionais no âmbito do Programa Minha Casa Minha Vida (MCMV). Desse total, 1,592 milhão de moradias foram destinadas para famílias com renda mensal de até $R \$ 1.600 ; 1,384$ milhão para os que ganham até $R \$ 3.275$ e 431.671 para os que se enquadram na renda entre $\mathrm{R} \$ 3.275$ e $\mathrm{R} \$ \mathbf{5}$ 5000. Das unidades habitacionais com financiamento contratado pelo MCMV, 1.857.815 foram construídas e 1.614.820 entregues. A média anual do financiamento imobiliário por governo até 2013 era a seguinte: FHC, 181,6 mil; Lula, 474 mil; Dilma, 1.095,5 mil.

Graças à investida no crédito com forma de enfrentamento da crise financeira internacional de 2008, a Caixa é o banco que mais conquistou participação no mercado de crédito. $O$ estoque de crédito do banco sextuplicou de junho de 2009 a dezembro de 2014, partindo de $\mathrm{R} \$ 99,2$ bilhões ( $R \$ 323,6$ bilhões em ativos) e atingindo $\mathrm{R} \$ 597,1$ bilhões (R\$ 1.064,7 bilhões em ativos) por causa do crescimento cumulativo de sua carteira de crédito imobiliário em longo prazo. Em operações de crédito, no final de 2014, a Caixa só estava abaixo do Banco do Brasil, que tinha $\mathrm{R} \$ \mathbf{6 4 5 , 0}$ bilhões em sua carteira de crédito. No ranking de ativos, a Caixa estava em terceiro lugar, depois de ultrapassar o Bradesco.

Deve-se lembrar que, antes da reestruturação patrimonial de 2001, com a transferência dos créditos imobiliários inadimplentes para a EMGEA, a Caixa chegou a ser o maior banco latino-americano em ativos. Esse tipo de crédito entra no balanço e, se não é securitizado e/ou amortizado, fica registrado em longo prazo na estatística.

Desde 2008, quando o BNDES passou a receber aportes periódicos de recursos do Tesouro Nacional, da ordem de $\mathrm{R} \$ \mathbf{4 0 0}$ bilhões, sua carteira de crédito saltou de 6,2\% para $10,6 \%$ do PIB. As alocações orçamentárias para capitalizar as Instituições Financeiras Públicas Federais (IFPF) se transformam em reservas de empréstimos. Estes 
empréstimos multiplicam a quantidade de dinheiro na economia, exacerbando ciclos de expansão ou atuando contra-ciclo de queda da renda.

Em termos de custo fiscal e Orçamento Geral da União, IFPF podem 'fazer mais por menos', isto é, gerar políticas públicas cujo gasto efetivo sai por cerca de $10 \%$ do custo fiscal potencial. São nove vezes mais, se comparar o valor em dinheiro necessário para executar diretamente políticas públicas com a mesma quantidade de recursos capitalizados nas IFPF para alavancar empréstimos (e tomar depósitos), pois o Índice de Basileia exige $11 \%$ do capital para cobertura dos empréstimos. Os empréstimos do banco público possuem impacto suficiente para multiplicar a quantidade de dinheiro na economia, exacerbando ciclos de expansão ou atuando contra ciclo de queda.

Todos os neoliberais estão fazendo o maior de seus esforços para criticar o governo social-desenvolvimentista e voltarem ao Poder de modo a completar o desmanche do Estado desenvolvimentista ocorrido nos anos 90. Por isso, atacam, sistematicamente, tanto o BNDES quanto a PETROBRAS.

Se porventura eles conseguirem o intento, derrubarão a possibilidade do País, na próxima década, emancipar de problemas no seu balanço de pagamentos pela exportação de petróleo extraído do pré-sal. Assim, como alavancou o financiamento a terceira maior hidrelétrica do mundo (Belo Monte) sem endividamento externo, só com o financiamento do BNDES se conseguirá erguer a indústria do petróleo no Brasil, já que o mercado de capitais aqui é raquítico e não há iniciativa particular para fomentar o desenvolvimento econômico.

\section{Atuação Social-Desenvolvimentista do BNDES}

O objetivo maior da crítica neoliberal é a atuação proativa do BNDES. De fato, em pleno período anterior ao 'apagão de 2001', o BNDES emprestou de 1997 a 1999 apenas R\$ 19 bilhões, anualmente, e só passou para o patamar de R\$ 26 bilhões em 2000 e 2001. Depois, o BNDES passou a ter um papel ativo no governo socialdesenvolvimentista e o valor anual, nos últimos dois anos, está em torno de R\$ 190 bilhões: dez vezes maior!

Por exemplo, financiou a construção da Usina Hidrelétrica de Belo Monte (AM), cujo empréstimo de $\mathrm{R} \$ 22,5$ bilhões para o projeto foi o maior da história do banco, correspondendo a $78 \%$ do total ( $\mathrm{R} \$ 28,9$ bilhões) a ser investido na hidrelétrica. Com isso, ao contrário do financiamento da hidrelétrica de Itaipu (PR), desta vez o país não recorreu ao endividamento externo.

A crítica oposicionista à atuação recente do BNDES é que ela seria baseada em concessão de 'subsídio' e 'favorecimento' ao organizar grandes empreendimentos em associação com grandes empresas brasileiras. Com essa 'escolha dos parceiros estratégicos', ele ofereceria subsídios e incentivaria a formação de conglomerados que, sob o argumento de melhoria da competitividade da indústria brasileira, atentariam contra o livre-mercado. 
Não cabe essa crítica de 'favorecimento', pois qualquer escolha de setores prioritários na estratégia de crescimento explicitada no PAC (Programa de Aceleração Econômica), evidentemente, exigia selecionar as empresas contempladas com financiamento. Isto foi realizado, transparentemente, inclusive as empresas foram nomeadas no site do Banco.

Defender isonomia entre empréstimos dirigidos aos grandes grupos, responsáveis pelos principais projetos em andamento, principalmente ligados à Petrobras, e às micros, pequenas e médias empresas era desculpa antes adotada para não se escolher o caminho do desenvolvimento. Era, então, coerente com a atitude passiva pro mercado. Em nome de 'não privilegiar clientes', emprestava apenas para se privatizar o patrimônio público.

O oposicionista a favor do livre-mercado estima o custo anual do subsídio, comparando o custo atual do financiamento da dívida pública (SELIC) com a TJLP. Aplica essa diferença ao montante da capitalização do Banco por seu controlador, o Tesouro Nacional, via empréstimo em longo prazo. Faz cálculos estáticos para resultados dinâmicos. Não contempla o investimento multiplicador de renda, a elevação da arrecadação fiscal e nem o pagamento futuro de dividendos. $O$ valor exato dos juros sobre a capitalização do banco só poderá ser conhecido no fim do financiamento. Poderá ser bem menor do que a quantia então estimada, ocorrendo uma futura convergência da TJLP e da Selic.

Sem visão estratégica sobre a obtenção de crescimento sustentado em longo prazo, a oposição só destaca o impacto fiscal dos empréstimos da União ao BNDES. Dado que os empréstimos têm custo indexado majoritariamente pela TJLP, haveria, em princípio, 'subsídio' igual à diferença entre o custo de mercado do financiamento da União, baseado em Selic, e a TJLP. Esse cálculo, visto isoladamente, pode suscitar conclusões equivocadas, pois ignora os ganhos fiscais resultantes das operações viabilizadas pelo empréstimo da União, entre eles:

1. o lucro do BNDES, que retorna à União por meio de dividendos, tributos e lucros retidos;

2. o ganho fiscal em curto prazo, decorrente da expansão do produto e da renda da economia; e

3. o ganho fiscal em longo prazo, resultante do fato de que a capacidade produtiva da economia será maior nos próximos anos, viabilizando o crescimento da demanda sem pressão inflacionária, maior Produto Interno Bruto (PIB) e arrecadação fiscal mais elevada.

O governo social-desenvolvimentista justifica a existência do BNDES para corrigir a lógica do mercado, baseada em expectativas pessimistas. Ele realoca recursos para setores prioritários, mas não tão lucrativos e atraentes para iniciativas particulares.

Há muita desinformação sobre a atuação do BNDES. Uma das principais diz respeito à correlação entre desembolsos dos bancos e a taxa de investimento, medida 
pela Formação Bruta de Capital Fixo (FBCF). Em 2013, 25,6\% da FBCF teve participação do banco, sendo que o desembolso do BNDES foi de $14,6 \%$ da FBCF. Portanto, o aumento do apoio do BNDES gerou elevação da formação de capital.

A crítica sobre o peso dos subsídios - calculado a partir da diferença entre o custo de captação do Tesouro e o juro subsidiado oferecido pelo BNDES - não leva em conta os benefícios gerados pelas operações do banco. Supondo um multiplicador de renda de 2,5, os benefícios acumulados entre 2008 e 20014 superam os custos em $R \$ 7,7$ bilhões. Para um multiplicador de 1,5, bastante conservador, o custo fiscal líquido do período é R\$19,8 bilhões, o que equivale a apenas 0,06\% do PIB.

Os neoliberais, quando estiveram no Poder, colocaram nos bancos públicos a função de carregar títulos de dívida pública, dando ao governo certa autonomia em relação aos bancos privados. A missão principal deles passou a ser obter lucros para pagar dividendos ao Tesouro Nacional, elevando o superávit primário. O BNDES apenas financiava a privatização do patrimônio público, executando o Programa Nacional de Desestatização.

Os idolatras do 'livre-mercado' chegaram até mesmo a questionar, embora não obtivessem apoio político para mudar, o que consideram um dogma ideológico dos social-desenvolvimentistas: o banco público usar, exclusivamente, os fundos sociais, evitando obtenção de lucros pelos bancos privados com dinheiro público.

Periodicamente, a oposição requenta a velha hipótese neoliberal, falseada pela realidade dos fatos: 'o desenvolvimento do mercado de capitais não ocorreu no Brasil por causa do BNDES'. Segundo seu raciocínio, o modelo de financiamento desenvolvimentista adotado no Brasil inibiu o mercado de capitais.

O argumento do'crowding-out financeiro'é que'os bancos públicos, concentrando os fundos sociais, restringe o crédito privado de longo prazo, sobretudo em face da ausência de mobilidade internacional de capitais. As empresas se tornam cada vez mais dependentes do governo para se financiarem e, ao serem abastecidas por ele, reduzem a demanda por instrumentos alternativos de financiamento privado'. Em outras palavras, a iniciativa privada não inicia nada porque o Estado brasileiro inicia tudo!

No Brasil, em casos como o do BB, da CEF e do BNDES, a implantação de instrumentos de governança inibidores é a solução alternativa que a oposição neoliberal aponta, pois é pouco provável que, no curto prazo, haja clima político para a privatização desses bancos. Como um second best face ao first best da privatização total se os neoliberais retornarem ao governo, provavelmente, providenciarão:

1. a venda de lotes expressivos de ações,

2. a montagem de Conselhos de Administração independentes do governo (e dependentes do setor privado), e

3. a fiscalização discriminatória do Banco Central. 
Nessa perspectiva, os bancos públicos brasileiros se tornariam irrelevantes ou desapareceriam por inanição - estado de um organismo que carece de um elemento indispensável à sua vida. A intenção da oposição neoliberal é levá-los, gradualmente, a um estado de esgotamento ou de extremo enfraquecimento, por falta de capitalização por parte do seu controlador, o Tesouro Nacional. Para a alegria de O Mercado!

\section{Programa de Financiamento Habitacional Minha Casa, Minha Vida}

De acordo com as primeiras avaliações do Minha Casa Minha Vida (MCMV), realizadas no início do segundo mandato do Governo Dilma, trata-se do maior Programa de Financiamento Habitacional já realizado na história do País.

Uma avaliação atuarial feita pela auditoria Deloitte Touche Tohmatsu no Fundo de Arrendamento Residencial (FAR), o veículo financeiro que abriga as operações da faixa de renda mais baixa do MCMV, apontou'uma deficiência total' de $\mathrm{R} \$ 28,830$ bilhões em dezembro de 2013. Ainda não foi divulgada a avaliação atuarial de 2014.

A 'deficiência' ocorre sobretudo porque o FAR assume compromissos com as construtoras para serem honrados nos anos seguintes. Mas só recebe dinheiro do Tesouro para cobrir essas despesas em parcelas anuais, dentro do Orçamento da União.

Assim, 'deficiência' não é a melhor palavra para se usar nessa circunstância, pois esses são compromissos assumidos com as construtoras que o Tesouro vai pagar à medida em que as obras forem executadas. Não há nenhuma obra que tenha deixado de receber em 2014.

O prazo de execução das obras contratadas é de 18 meses, por isso o grosso dos compromissos deve ser pago neste ano de 2015 e no início do próximo. Algumas obras, porém, só devem começar mais para meados deste ano, e outras estão atrasadas. Por isso, uma parte residual dos pagamentos a construtoras está previsto para acontecer apenas em 2017.

As verbas previstas para o MCMV em 2015 somam R\$ 18 bilhões, dos quais $R \$$ 14 bilhões estão inscritas no projeto de Orçamento e outros $\mathrm{R} \$ 4$ bilhões são restos a pagar. O governo afirma que o programa de ajuste fiscal vai preservar gastos sociais como esse.

Até agora, foram contratadas 1,322 milhão de moradias na faixa 1, voltada à renda mais baixa feita dentro do FAR. Em setembro de 2015, será anunciada uma terceira etapa do programa, com o compromisso de contratar mais três milhões de moradias. Ainda não está claro qual será a meta de contratação para a faixa 1, que atende famílias com renda familiar de até $\mathrm{R} \$ 1.600,00$ mensais, dependente de maiores aportes diretos (subsídios) do governo. As demais faixas do programa (2 e 3) contam com recursos do Fundo de Garantia do Tempo de Serviço (FGTS).

A equação financeira do MCMV dentro do FAR depende fundamentalmente de recursos do Tesouro porque as prestações pagas pelos beneficiários - entre $\mathrm{R} \$ 25$ 
e R\$ 80 mensais - cobrem apenas uma pequena parcela do valor dos imóveis. As transferências ao FAR são feitas sob a forma de subsídios aos beneficiários faixa 1 do MCMV, abatendo até $95 \%$ do valor das moradias.

Em 2014, as receitas do FAR com as prestações pagas pelos mutuários somaram R\$ 194 milhões. Este valor não cobre nem a taxa de administração paga ao agente financeiro, que, a título de comparação, foi de R\$ 246 milhões no exercício de 2013.

Os altos índices de inadimplência também reduzem as receitas com as prestações. A Caixa calcula que, em 2014, o índice de inadimplência tenha fechado em 18,5\%, considerando contratos com atraso superior a 90 dias. É um índice bem superior aos demais financiamentos habitacionais da Caixa, de 1,84\%. As perdas na faixa 1 do programa MCMV são assumidas pelo próprio FAR, cujo único cotista é o Tesouro. A Caixa não assume nenhum risco de crédito nessas operações.

$O$ índice de inadimplência só não é maior porque o FAR vem lançando a prejuízo parte dos créditos. Em 2013, foram R\$1 190,5 milhões. A carteira de crédito do FAR somava $\mathrm{R} \$ 1,963$ bilhão em dezembro de 2014. A baixa de créditos a prejuízo segue as regras do Banco Central.

Na sua avaliação atuarial, a Deloitte Touche Tohmatsu utilizou como hipótese uma inadimplência de 48,09\%, construída com base no histórico de inadimplência do MCMV. E percentual de inadimplência é mais alto porque leva em conta atrasos a partir de um dia. A Caixa discutiu com a auditoria, na avaliação atuarial de 2014, o uso do critério de inadimplência do $B C B$, que considera inadimplentes operações com atraso de mais de 90 dias.

Para se ter uma ideia do peso relativo desse programa social, os gastos com subsídios repassados pelo governo federal passaram de 0,25\% para 1,05\% do PIB entre 2010 e 2014. Desse universo, o MCMV, que representa um dos maiores pesos, o percentual saiu de $0,04 \%$ para $0,35 \%$ do PIB no período. Enquanto isso, no ano de 2014 , os juros nominais atingiram $\mathrm{R} \$ 311,4$ bilhões (6,07\% do PIB), comparativamente a $R \$ 248,9$ bilhões (5,14\% do PIB) em 2013. Política habitacional representa incentivo à acumulação de uma riqueza familiar de maior benefício social do que a concentração da riqueza financeira através da expansão da renda do capital.

No entanto, o pesquisador do Instituto Brasileiro de Economia (IBRE-FGV), Gabriel Leal de Barros, prefere destacar o peso semelhante dos gastos com o MCMV com todo o investimento dos ministérios da Saúde e da Educação, $68 \%$ de todo o gasto com o programa Bolsa Família e equivalente a todo o pagamento de dividendos das estatais ao Tesouro. O custo também pode ser comparado a toda a compensação do Tesouro ao INSS pela desoneração da folha de pagamentos.

É muito difícil separar, precisamente, as 'ações de Robin Hood' da Caixa: transferir ganhos com 'os ricos' (ações comerciais) para subsidiar os pobres (ações sociais). Na realidade, muito do que ela ganha, aplicando dinheiro que é patrimônio dos trabalhadores (FGTS) ou dos que reivindicam justiça (depósitos judiciais), é revertido para os necessitados de subsídios sociais para aquisição de Habitações de Interesse 
Social. Em outros termos, os ganhos em Tesouraria permitem o oferecimento de 'produtos sociais' no ponto-de-equilíbrio, pagando todas as despesas e remunerando o controlador, porém sem a maximização do lucro como buscam sempre os bancos comerciais privados.

Um grande diferencial entre bancos públicos e bancos privados está na compensação por Rendas de Administração de Fundos Sociais (FGTS, FAT, FCO, FNE, FINOR, etc.), Programas Sociais e Loterias e Rendas de Serviços de Arrecadações e Convênios, para os bancos públicos, de suas menores Rendas de Tarifas Bancárias, Rendas de Cartão de Crédito e Rendas de Administração de Fundos de Investimentos. Os bancos privados têm receitas muito maiores nestas últimas atividades.

Segundo Fernando Torres (Valor, 05/01/15), 'nos primeiros nove meses de 2014, a Caixa Econômica teve lucro de $\mathrm{R} \$$ 4,8 bilhões antes do pagamento de Imposto de Renda e CSLL. Mas esse resultado se explica essencialmente por Fundo de Garantia do Tempo de Serviço (FGTS), depósitos judiciais e loterias, e não pela atividade de concessão de crédito e prestação de serviços tradicional'.

Para cuidar com exclusividade do FGTS, que tinha, em outubro de 2014, R\$ 400 bilhões em ativos, a Caixa cobra 1\% de taxa de administração dos trabalhadores e com isso ganhou ao longo de 2014 até setembro R\$ 2,89 bilhões. Descontados os custos reportados de $\mathrm{R} \$ 373$ milhões, o lucro com a operação do fundo fica em $\mathrm{R} \$$ 2,51 bilhões.

Já a captação da Caixa por meio de depósitos judiciais teve saldo médio de R\$ 47,3 bilhões no ano de 2014 , com custo contabilizado de $4,11 \%$ no ano até setembro, ante um CDI acumulado de 7,83\% no mesmo período. A economia proporcionada por meio do funding mais barato foi de $\mathrm{R} \$ 1,76$ bilhão.

Só com esses dois fatores já se chega a um ganho de $R \$ 4,28$ bilhões, suficiente para assegurar quase $90 \%$ do lucro antes de impostos obtido pela Caixa nos primeiros nove meses de 2014.

A análise do resultado com loterias é mais difícil, já que a Caixa aglutinou parte das despesas com lotéricas a partir de 2013 dentro da linha de gastos com 'parceiros comerciais', o que impede uma precisão no cálculo. A receita com casas lotéricas apontada no balanço foi de $\mathrm{R} \$ 900$ milhões de janeiro a setembro, enquanto o custo passível de ser diretamente alocado pode ser estimado em cerca de R\$ 300 milhões, com base na abertura de dados que era feita até o exercício de 2012, o que dá um resultado positivo de mais $\mathrm{R} \$ 600$ milhões.

Ainda que uma parte relevante da linha de despesas com 'parceiros comerciais', no valor de R\$1,58 bilhão, deva ter relação com as lotéricas, a Caixa tampouco discrimina as receitas de serviços e com operações de crédito que consegue capturar pelo fato de possuir as loterias como rede de distribuição, o que pode equilibrar a conta.

Em síntese, a Caixa tem lucro, devido à cobrança de uma taxa para administrar o dinheiro dos trabalhadores no FGTS, à perda de custo de oportunidade imposta pelos 
depósitos judiciais a quem reclama na Justiça, e aos 'jogos de azar'. Porém, no fim das contas, fica todo o ganho com o governo, que tem $100 \%$ do capital da Caixa.

Outro ponto relevante do modelo atual da Caixa tem relação com a estrutura de capital da instituição, que tem pouco mais de metade do patrimônio líquido (55\%) formada por instrumentos híbridos que rendem TJLP ao governo. Quando se observa o resultado da Caixa, nos últimos 12 meses até setembro de 2014, e se faz um cálculo de retorno sobre o patrimônio líquido médio, a rentabilidade fica em 12,6\%, quando o cálculo considera lucro e remuneração de híbridos no numerador e capital próprio e híbridos no denominador. É um nível baixo para um banco privado, mas aceitável para um estatal.

No entanto, Alex Ribeiro (Valor, 23/12/14) anunciou que‘a Caixa obteve um retorno sobre o patrimônio líquido de $17,8 \%$ no terceiro trimestre de 2014 , não muito inferior aos concorrentes privados'. Aquele cálculo de rentabilidade patrimonial, considerando os Instrumentos Híbridos de Capital e Dívida (IHDC), é falho. Eles são representados por diversos tipos de títulos de dívida ou contratos para captação de recursos financeiros para capitalização da instituição financeira, que devem ser contabilizados no Patrimônio Líquido, porque fazem parte do PR (Patrimônio de Referência). O BCB permite que os IHDC sejam capazes de aumentar o grau de capitalização e, consequentemente, os níveis de alavancagem da instituição financeira.

Torres argumenta que, no modelo atual, a parcela do patrimônio pertencente aos detentores de títulos híbridos (leia-se o Tesouro Nacional) foi remunerada por TJLP, a $5 \%$ ao ano, enquanto o 'capital dos acionistas' (de novo o Tesouro Nacional) recebeu 23\%'. Como atualmente o Tesouro é o único nas duas pontas, essa discrepância entre risco e retorno não é um problema.

A equipe da Caixa, no primeiro semestre de 2007, construiu junto ao Tesouro Nacional uma engenharia financeira então inédita via 'empréstimos perpétuos' do controlador para a controlada. Ele concederia empréstimo perpétuo, que jamais se amortizaria, mas que seria remunerado com o pagamento dos mesmos juros de títulos de dívida pública no maior prazo então lançado. A Caixa compraria esses títulos com o valor do empréstimo recebido, para fazer hedge desse pagamento de juros: o que receberia com uma mão, pagaria com a outra. Seria, então, um 'jogo de ganha-ganha' de natureza contábil, de modo que as agências de avaliação de risco verificassem que a Caixa é um banco de risco soberano, pois é controlada pelo Tesouro Nacional, que jamais quebra.

Essa inovação financeira foi útil para o Tesouro Nacional captar recursos com títulos de dívida pública que ofereciam risco soberano e, com eles, capitalizar todos os bancos públicos para fazerem uma atuação anticíclica após a explosão da crise de 2008. Estes bancos reciclavam esse capital, concedendo crédito subsidiado para setores estratégicos prioritários para a emergência da economia brasileira. 


\section{Atuação Anticíclica e Crowding Out Creditício}

Depois de um crescimento significativo, no período da crise, os desembolsos do BNDES já apresentavam moderação nos anos recentes, tendo em vista o anúncio de menores transferências para o banco. No início de 2014, o BNDES representava $24,15 \%$ de todo o crédito direcionado, $37 \%$ do crédito dos bancos públicos e $19,13 \%$ do crédito total da economia brasileira. Mesmo com essa moderação no ritmo de crescimento, os bancos públicos continuavam respondendo por mais da metade do mercado de crédito do país, posição conquistada em junho de 2013 , quando a participação relativa passou dos $50 \%$ pela primeira vez.

Segundo o Relatório de Inflação, publicado pelo BCB em março de 2015, as carteiras das instituições financeiras públicas, privadas nacionais e estrangeiras representaram, na ordem, 54,3\%, 31,2\% e 14,5\% do total de crédito do sistema financeiro em fevereiro de 2015. Carolina Mandl e Felipe Marques (Valor, 30/09/13) avaliam que 'um eventual recuo dos bancos públicos daqui para a frente vai acabar deixando gente sem crédito'. $\mathrm{Na}$ avaliação de executivos de bancos privados, embora pretendam retomar parte do espaço perdido no crédito a empresas, pouco deve mudar em sua baixa disposição de emprestar para pessoas com maior risco de inadimplência. 'As métricas de risco dos bancos privados não vão se alterar. Por isso, a consequência da retração das instituições públicas é que algumas pessoas vão ficar sem crédito'.

Os bancos privados são pouco propensos a replicar algumas táticas que os públicos usaram para cativar sua clientela. No crédito a veículos, por exemplo, as instituições oficiais chegaram a fazer operações de 60 meses sem entrada. Também permitem que o cliente faça uma pausa no pagamento do empréstimo por certo tempo.

Os bancos públicos acabaram criando uma demanda que não existia. Quando alongam prazo, dão carência ou reduzem taxas, colocam no mercado pessoas que, antes, não pensavam em buscar crédito.

No crédito à empresas, porém, os bancos privados acreditam que é possível recuperar parte do mercado perdido. Isso porque os bancos públicos, principalmente a Caixa Econômica Federal, vinham ofertando à grandes companhias, com boa qualidade de crédito, taxas abaixo daquelas em que os privados aceitavam competir. Com o fim da capitalização e/ou os 'empréstimos perpétuos' do Tesouro Nacional para os bancos públicos, a partir de 2015, o mercado de crédito deve ficar mais seletivo em relação ao preço das operações, em busca de maior rentabilidade. Isso deve gerar equilíbrio maior entre bancos públicos e privados.

Nas linhas de capital de giro, que representam quase $30 \%$ do crédito a empresas, houve uma acentuada diferença entre o crescimento de públicos e privados. Nesse período pós-crise, os públicos avançaram $34,9 \%$ ante recuo de $2,8 \%$ dos demais. Em dezembro de 2012, enquanto os bancos públicos emprestavam na linha com juros de $13,6 \%$ ao ano e 44,3 meses de prazo, em média, os privados nacionais cobravam 17,4\% aa para 29,3 meses. 
Já em relação ao BNDES, os banqueiros do setor privado dizem acreditar que uma eventual redução nos desembolsos para grandes empresas pode estimular a busca pelo mercado de capitais.

Se os bancos privados manifestam pouca vontade para assumir o espaço no mercado deixado pelos públicos, fica em dúvida o avanço do crédito como um todo daqui para frente. É difícil ver o crédito como fonte de aceleração do crescimento nos próximos anos.

Desde o quarto trimestre de 2013, segundo informaram Alex Ribeiro e Cristiano Romero (Valor, 27/09/13), os bancos públicos receberam ordem da presidente Dilma Rousseff de conter o seu avanço no mercado de crédito para evitar uma maior presença estatal no sistema financeiro. A Caixa, que já vinha cortando a concessão de empréstimos a grandes corporações, foi obrigada também a desacelerar a oferta de crédito a pessoas físicas. O BNDES estuda reduzir linhas de crédito criadas na crise de 2008 e dirigir seus esforços para o financiamento das concessões.

O governo reduziu algumas linhas de crédito criadas em 2008 e 2009, quando a economia brasileira teve forte contração como reflexo da crise mundial. A principal delas era o Programa de Sustentação do Investimento (PSI), que, desde meados de 2009 até o final de 2013, emprestou R\$ 237 bilhões com taxa de juros negativa, isto é, abaixo da taxa de inflação.

O diagnóstico do governo é que os bancos públicos tiveram papel anticíclico fundamental nos anos recentes, garantindo a oferta de crédito e ajudando a sustentar a demanda agregada em um período de retração dos bancos privados. Agora, quando crescem as críticas das agências internacionais de rating sobre os riscos fiscais da ação dos bancos públicos, devido ao crescimento da dívida bruta federal, seria o momento de caminhar para uma 'normalização'. O governo age com o intuito de minimizar o risco de um rebaixamento do risco soberano.

O PSI foi criado pelo Ministério da Fazenda. O funding era do BNDES, que cobrava juro de 3,5\% ao ano. A linha era oferecida para financiar bens de capital (máquinas e equipamentos), incluindo ônibus e caminhões. Neste caso, o juro era um pouco maior: $4 \%$ ao ano. O custo do crédito era inferior também ao do FINAME, linha tradicional do BNDES para financiar a aquisição de bens de capital.

O PSI estava programado para acabar em 31 de dezembro de 2013. O BNDES não se opunha ao fim do programa ou a uma redução drástica nos valores e no subsídio oferecidos com desaceleração das concessões com base no PSI. O governo manteve o programa, mas sob condições mais estritas.

Outra linha do BNDES revista foi a do PROGEREN (Programa de Apoio ao Fortalecimento da Capacidade de Geração de Emprego e Renda), criada em 2004 para financiar capital de giro.

A Caixa reduziu de forma drástica a concessão de empréstimos a grandes corporações, desacelerando o ritmo de crescimento da sua carteira de crédito de mais de $40 \%$ ao ano. No exame de alternativas, surgiu a hipótese de tornar ainda mais 
conservadores os modelos de risco de crédito, restringindo a oferta. Outra alternativa seria subir os juros e fazer parte da demanda por crédito se deslocar para os bancos privados. Ambas as hipóteses significariam crescer em ritmo menos intenso em crédito a pessoas físicas e pequenas empresas.

No caso do Banco Brasil, não havia a necessidade de rever muito a estratégia. O banco tem capital aberto e está submetido à disciplina de mercado. O BB tem contribuído para atrair bancos privados aos consórcios que financiarão as concessões.

Diante desse novo cenário que se desenhava, os bancos privados esperavam encerrar o ano recuperando um'market-share' dos bancos públicos. Se esse movimento se concretizasse, marcaria a interrupção de um ciclo que teve início em 2008, havendo uma realocação de mercado de crédito dos bancos públicos para os privados.

\section{Sistema Bancário Brasileiro em Comparação com Outros Sistemas}

Reconhecidos pela solidez e pela lucratividade, os bancos brasileiros também aparecem no topo do ranking das instituições financeiras mais ineficientes e com o maior custo do mundo, segundo relatório do BIS ('o banco central dos bancos centrais'), resumido em reportagem de Toni Sciarretta (FSP, 02/06/14). Por ineficiência, o BIS entende o elevado custo administrativo (processos, instalações, tecnologia) e de pessoal pela quantidade relativamente baixa de negócios e de ativos (financiamentos, disponibilidades, títulos) gerados.

Os bancos brasileiros, que cumprem múltiplas funções, não são tão eficientes e não têm escala adequada para diluir o peso dos custos fixos. Falta compartilhar caixas eletrônicos, serviços comuns de transporte de dinheiro, tecnologia, etc. No ranking do grau de ineficiência, medido pela relação custos operacionais/ativos, o Brasil com $3,28 \%$ é seguido por Estados Unidos (3,03\%), Rússia (2,68\%) e Índia, países que, como - Brasil, necessitam elevar os negócios bancários sem ter de expandir os gastos.

Por outro lado, o Brasil (com 1,62\%) é terceiro colocado no ranking dos bancos mais lucrativos do mundo em termos de \% de ativos. Só perde para Rússia (2,04\%) e China (1,86\%), superando Índia (1,41\%), Austrália (1,28\%), Estados Unidos (1,24\%) e Canadá (1,06\%). O principal motivo é o ganho com os chamados spreads, a diferença entre os juros que o banco paga ao investidor e o quanto cobra para emprestar a outro cliente. Esse ranking de lucratividade desconsidera o pagamento de impostos e mede a lucratividade face ao tamanho dos ativos, uma medida do retorno face ao risco da alavancagem financeira.

O Brasil só perde para a Itália nas provisões para créditos concedidos a devedores duvidosos. Supostamente, essas provisões seriam para cobrir eventuais perdas com inadimplências dos empréstimos.

O BNDES dá sinais consistentes de mais eficiência se comparado a seus pares internacionais e até mesmo a bancos privados brasileiros. A conclusão é de um estudo 
conduzido pelo economista Felipe Rezende, a partir dos balanços e demonstrações financeiras de bancos públicos e privados entre 2000 e 2014.

O grau de eficiência bancária é medido, precisamente, pela relação entre despesas (de pessoal e outras administrativas) e receitas (resultado bruto de intermediação financeira e receita de prestação de serviços). Despesas de pessoal e outras administrativas de Bancos de Desenvolvimento são muito menores do que as de Bancos de Varejo que operam rede de agências.

Comparações de eficiência - (DP+ODA)/(RBIF+RPS) — não só tendem a cometer a falácia de agregação, como também ocultam diferença muito importante para a gestão pública. Como visto, os bancos públicos propiciam grandes alavancagens financeiras de recursos públicos.

Grau de eficiência é indicado por ([LL'+ DF] / PT) > (LL / PL) onde: $\mathrm{PT}=\mathrm{PL}+\mathrm{P} 3^{\circ}$.

Rentabilidade patrimonial ou ROE (= LL/PL) e rentabilidade sobre ativos - ROA (= LL/AT) — são indicadores de rentabilidade para acionistas. Provisões sujeitas às ações discricionárias sobre o balanço e tributações influenciam-nos.

Ao longo do período, especialmente no pós-crise de 2008, o autor identificou uma expressiva incapacidade dos bancos privados brasileiros em operar com spreads (diferença entre a taxa cobrada nos empréstimos e a taxa de juros paga para captação dada em pontos percentuais) mais alinhados com o resto do sistema financeiro mundial. Mesmo com esses altos spreads, que constituem a margem para cobrir despesas administrativas, inadimplência, cunha fiscal e lucro bancário, geram retornos sobre capital (ROE) comparáveis aos bancos do resto do mundo. Tal situação, segundo ele, seria consequência de:

1. os elevados compulsórios praticados no Brasil,

2. os custos operacionais altos e

3. as fontes instáveis de funding.

O trabalho indica que o BNDES opera com um retorno sobre ativos mais baixo quando comparado aos bancos privados brasileiros - de 0,9\% em dezembro de 2013, segundo dados colhidos pelo autor -, mas o faz com uma alavancagem maior para gerar um retorno sobre patrimônio (ou capital) acima de seus pares, isto é, outros Bancos de Desenvolvimento (WB, BID, China BD), de 16,9\% em dezembro de 2013.

O retorno sobre o patrimônio de Itaú-Unibanco e Bradesco ficou acima disso no período - em $20,9 \%$ e $18 \%$, respectivamente -, mas é alcançado à custa de um retorno sobre ativos bem mais elevado - de 1,9\% e 1,6\%, respectivamente, no período -, além de uma das menores alavancagens entre os sistemas bancários globais.

Os bancos brasileiros têm os maiores spreads do mundo, incluindo altas despesas com empréstimos, para gerar um retorno sobre o patrimônio compatível com o esperado pelos acionistas. Os outros bancos selecionados operam com spreads significativamente menores, assim como despesas de empréstimos, e geram um ROE satisfatório. Essa é a grande diferença entre eles. 
Como exemplo, Resende cita uma comparação entre sistemas financeiros de Brasil e Austrália que indica que, em abril de 2013, os quatro maiores bancos brasileiros apresentavam ROE entre 12\% e 18,5\%, diante de um spread médio de 10,4\%. Na Austrália, o spread médio era de apenas 2,6\%, com ROE dos quatro maiores entre $9,3 \%$ e $16,5 \%$.

Segundo Rezende, como as instituições privadas buscam altos retornos sobre seus ativos de modo a oferecer retornos sobre o capital mais consistentes, tanto os custos dos empréstimos quanto a posição em carteira desses bancos em títulos públicos são elevados. Se os bancos privados decidissem operar com spreads baixos, os acionistas teriam que se preparar para receber retornos sobre o capital bem menores.

Em contraposição ao que chama de 'ineficiência' privada, o autor ressalta que o BNDES vem demonstrando forte vantagem competitiva expressa na capacidade de operar com baixos spreads em relação aos produtos bancários tradicionais e, ainda assim, gerar um retorno sobre o capital em níveis até mais altos do que o padrão internacional de outros bancos de desenvolvimento. "Muito da discussão se dá no âmbito de que o BNDES tem uma vantagem competitiva em função dos seus custos de captação, mas, na verdade, a vantagem é a capacidade do banco em operar com margens de spreads muito baixas."

Para Rezende, o argumento de que taxas de juros de longo prazo bem mais atrativas impedem o desenvolvimento do mercado de capitais, tirando competitividade dos privados, é falacioso. "É a Selic muito alta e volátil que é o problema. Essa volatilidade traz perdas muito grandes para ativos de longo prazo e tem que ser minimizada", diz. Prova disso é que com a subida dos juros, a partir de abril de 2013, puxada pela ameaça de alta das taxas americanas, vários desses bancos privados tinham uma exposição grande em títulos públicos de longo prazo (NTN-B) e perderam com a marcação-amercado dos papéis.

Cabe fazer a comparação, dentro desses mesmos critérios, entre os bancos comerciais de varejo brasileiros: os privados nacionais - Itaú e Bradesco - e estrangeiros - Santander e HSBC - e os públicos - BB e Caixa. Dada a baixa capitalização realizada por seu controlador (Tesouro Nacional) e seu alto grau de alavancagem média $(30,4)$, cujos ativos predominantes são financiamentos imobiliários em longo prazo, inclusive os subsidiados, o ROE da Caixa é o maior (26,2\%), embora o ROA $(0,86 \%)$ seja o menor.

Na Tabela 1, destacam-se a queda relativa da carteira de títulos - de 39\% para $26 \%$ e o aumento relativo do market share da carteira de empréstimos - de 38\% para 49\% - dos bancos públicos (BB e CEF) entre dezembro de 2009 e dezembro de 2014. No mercado de crédito, os privados nacionais perderam 3 pontos percentuais (pp) e os estrangeiros, 4 pp. Os públicos também ganharam mercado em depósitos totais (7 pp) e aumentaram mais patrimônio líquido (4 pp). Com queda relativa no carregamento de títulos de dívida pública, diminuíram relativamente captações em mercado aberto (3 pp). Com essa atuação anticíclica, o lucro líquido do Banco do Brasil caiu de $26 \%$ para $18 \%$ do total do setor bancário. Por sua vez, a Caixa elevou o seu de $8 \%$ para $11 \%$. 
Elevação significativa obtiveram Itaú e o Bradesco, em conjunto, de 41\% para 55\%. Enquanto isso, o Santander ficou com sua parcela estagnada e o HSBC passou de lucro para prejuízo. Não à toa, foi vendido para o Bradesco em 2015.

Nesta Tabela, destacam-se ainda a elevação da concentração bancária nesses seis bancos, no período $2009-2014$, em ativos (de $81 \%$ para $83 \%$ ), créditos (de $82 \%$ para $86 \%$ ), depósitos (de $85 \%$ para $87 \%$ ), e mercado aberto (de $85 \%$ para $87 \%$ ).

Tabela 1 - 6 Maiores Bancos e o Consolidado do Sistema Financeiro Nacional

\begin{tabular}{|c|c|c|c|c|c|c|c|c|c|c|c|c|}
\hline 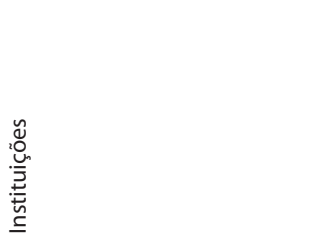 & 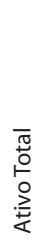 & 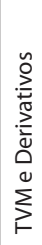 & 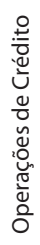 & 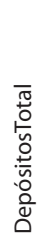 & 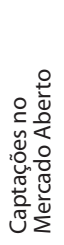 & 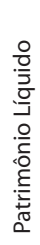 & 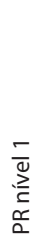 & 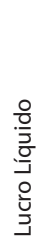 & 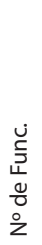 & 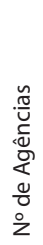 & 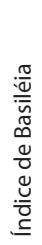 & 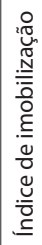 \\
\hline \multicolumn{13}{|l|}{ Data-base: Dezembro/2014 } \\
\hline BANCO DO BRASIL & $\stackrel{\circ}{\circ}$ & $\stackrel{\circ}{\check{2}}$ & ڤें & ڤั & $\stackrel{\circ}{\stackrel{\circ}{N}}$ & $\stackrel{\circ}{\stackrel{2}{2}}$ & $\stackrel{\circ}{\infty}$ & $\stackrel{\circ}{\infty}$ & & 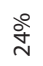 & $\bar{\sigma}$ & $\tilde{\text { ก }}$ \\
\hline CAIXA ECONOMICA FEDERAL & $\stackrel{\circ}{\stackrel{2}{ }}$ & ㅇํㄴ & 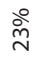 & 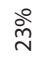 & $\stackrel{\circ}{\grave{~}}$ & ๑̊ & $\stackrel{\circ}{\grave{2}}$ & 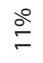 & & ㅇํํ & $\bar{\sigma}$ & $\underset{⿱}{+}$ \\
\hline Subtotal de Bancos Públicos & $\stackrel{\circ}{\infty}$ & iें & ஓे & 产 & $\stackrel{\circ}{m}$ & $\stackrel{\circ}{\stackrel{\circ}{N}}$ & ठें & ळे & & ळे & $\underset{\sim}{N}$ & $\begin{array}{l}0 \\
\dot{m}\end{array}$ \\
\hline ITAU & $\stackrel{\circ}{\infty}$ & $\stackrel{2}{\stackrel{2}{2}}$ & ㅇํㅁ & $\stackrel{\circ}{\stackrel{2}{ }}$ & $\stackrel{\grave{\nu}}{\sim}$ & ڤે & ڤั & $\frac{\circ}{m}$ & & $\stackrel{\circ}{\stackrel{2}{2}}$ & $\stackrel{g}{6}$ & $\bar{g}$ \\
\hline BRADESCO & $\stackrel{\circ}{\stackrel{\circ}{+}}$ & 。̊ & 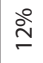 & $\stackrel{\circ}{\check{2}}$ & 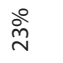 & $\stackrel{\circ}{\circ}$ & ㅇํํ & $\stackrel{\circ}{\stackrel{\sim}{\sim}}$ & & ठे̀ & $\underset{\mathscr{L}}{\underline{0}}$ & $\stackrel{m}{f}$ \\
\hline $\begin{array}{l}\text { Subtotal de Bancos Privados } \\
\text { Nacionais }\end{array}$ & ڤે̀ & ஓे̀m & 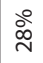 & $\stackrel{\circ}{\stackrel{\circ}{\sim}}$ & ㅇํ & ஓे & 今े & 今े & & $\stackrel{\circ}{\stackrel{0}{m}}$ & $\stackrel{\dot{m}}{m}$ & ڤั \\
\hline SANTANDER & ○े & 옹 & ळ & ळ & $\stackrel{\circ}{\infty}$ & $\stackrel{\text { mे }}{\mathrm{m}}$ & 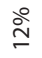 & ஓे & & 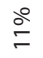 & $\stackrel{\stackrel{n}{\sim}}{\stackrel{2}{\sim}}$ & సે \\
\hline HSBC & ஓे & ஓे & ڤे & ஓे & ঃे & $\stackrel{\circ}{\stackrel{\circ}{ }}$ & 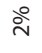 & 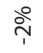 & & $\stackrel{\circ}{\circ}$ & $\bar{m}$ & 옴 \\
\hline $\begin{array}{l}\text { Subtotal de Bancos Privados } \\
\text { Estrangeiros }\end{array}$ & $\stackrel{\circ}{\grave{~}}$ & ㅇํํ & ○े & $\stackrel{\circ}{=}$ & $\stackrel{\infty}{\infty}$ & ㅇํㅁ & $\stackrel{\circ}{m}$ & $\stackrel{\circ}{~}$ & & 음 & $\stackrel{\bullet}{\circ}$ & in \\
\hline $\begin{array}{l}\text { Subtotal dos Top } 6 \text { Bancos } \\
\text { Comerciais }\end{array}$ & $\stackrel{\circ}{\infty}$ & $\stackrel{\circ}{n}$ & ஓें & $\stackrel{\circ}{\infty}$ & $\stackrel{\circ}{\infty}$ & ڤั & $\stackrel{0}{\stackrel{0}{\wedge}}$ & ڤั̀ & & ळँ & ֶั้ & $\underset{\substack{\infty \\
\infty}}{\stackrel{\sigma}{\infty}}$ \\
\hline $\begin{array}{l}\text { Total Consolidado Bancário I } \\
\text { (96 Instituições) }\end{array}$ & ஃे & ठे & ठें & ळे & ळे & ठे & ○े & ळे & & ○े & & \\
\hline $\begin{array}{l}\text { \% de Participação Consolidado } \\
\text { Bancário I }\end{array}$ & $\hat{\infty}$ & $\stackrel{\hat{\infty}}{\infty}$ & $\underset{\sim}{\infty}$ & హ゙ & के & $\underset{\infty}{ \pm}$ & ๙ू & @̊ & & ूे & & \\
\hline $\begin{array}{l}\text { \% Top } 6 \text { no Sistema Financeiro } \\
\text { Nacional ( } 1565 \text { IF) }\end{array}$ & के & ஓे & ஓ̊̀ & $\frac{\circ}{\infty}$ & $\frac{\circ}{\infty}$ & خे̀ & & 。ें & & $\frac{\circ}{a}$ & & \\
\hline
\end{tabular}


Tabela 1 (cont.) - 6 Maiores Bancos e o Consolidado do Sistema Financeiro Nacional

\begin{tabular}{|c|c|c|c|c|c|c|c|c|c|c|c|c|}
\hline 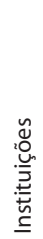 & $\begin{array}{l}\bar{\pi} \\
\stackrel{0}{0} \\
\stackrel{0}{0} \\
\stackrel{2}{2}\end{array}$ & 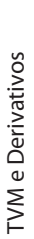 & 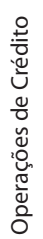 & $\begin{array}{l}\bar{\pi} \\
\stackrel{0}{0} \\
\frac{0}{n} \\
\stackrel{+}{n} \\
.0 \\
\frac{0}{2} \\
0\end{array}$ & 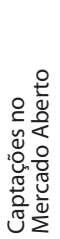 & 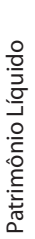 & 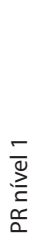 & $\begin{array}{l}\frac{0}{0} \\
\frac{0}{3} \\
\frac{0}{3} \\
0 \\
\frac{0}{3}\end{array}$ & 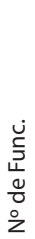 & 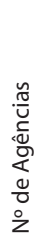 & 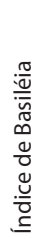 & 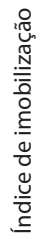 \\
\hline
\end{tabular}

Data-base: Dezembro/2009

\begin{tabular}{|c|c|c|c|c|c|c|c|c|c|c|c|}
\hline BANCO DO BRASIL & ঐ̊̀ & 。ํ & 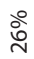 & 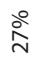 & ㅇํㅇ & $\stackrel{\circ}{\mathrm{m}}$ & ㅇํํ & ঐ̊ & 운 & $\stackrel{\circ}{\underset{\sim}{+}}$ & 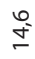 \\
\hline CAIXA ECONOMICA FEDERAL & $\stackrel{\circ}{\approx}$ & $\frac{\circ}{\sim}$ & $\stackrel{\stackrel{\circ}{~}}{ }$ & $\stackrel{\stackrel{\circ}{+}}{+}$ & 응 & in & $\stackrel{\infty}{\infty}$ & ๙े & 음 & $\stackrel{1 n}{\check{-}}$ & $\stackrel{0}{0}$ \\
\hline Subtotal de Bancos Públicos & ஓे & ஓे & $\stackrel{\circ}{\infty}$ & $\frac{\circ}{\sigma}$ & 。̊̊ & $\stackrel{\circ}{\stackrel{0}{2}}$ & ஓे & $\frac{8}{\dot{\gamma}}$ & 今̊ & $\frac{1 n}{m}$ & 믐 \\
\hline ITAU & ๙̊ & $\stackrel{\stackrel{\circ}{m}}{\square}$ & $\stackrel{\stackrel{0}{2}}{-}$ & $\stackrel{\circ}{6}$ & \̊ & $\stackrel{\infty}{\infty}$ & $\stackrel{\stackrel{Ð}{~}}{\stackrel{\circ}{ }}$ & ๙े & $\stackrel{\text { ஸे }}{\text { N }}$ & $\stackrel{0}{ }$ & $\stackrel{a}{\sim}$ \\
\hline BRADESCO & 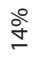 & ઠे & $\stackrel{\stackrel{\circ}{+}}{\circ}$ & $\stackrel{\stackrel{\circ}{+}}{\circ}$ & ๙े & ㅇํㅁ & $\stackrel{2}{\stackrel{2}{\stackrel{2}{2}}}$ & $\stackrel{\stackrel{\circ}{+}}{+}$ & $\stackrel{\circ}{\stackrel{2}{2}}$ & $\stackrel{\infty}{\stackrel{\infty}{N}}$ & iั \\
\hline $\begin{array}{l}\text { Subtotal de Bancos Privados } \\
\text { Nacionais }\end{array}$ & 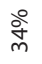 & $\stackrel{\stackrel{\circ}{N}}{\grave{N}}$ & $\frac{\circ}{m}$ & 仓े & $\frac{d}{\frac{\pi}{2}}$ & $\stackrel{\stackrel{一}{m}}{m}$ & $\frac{d}{\frac{\pi}{2}}$ & $\stackrel{\circ}{m}$ & ஓे & $\stackrel{\text { † }}{\mathrm{m}}$ & $\stackrel{0}{\infty}$ \\
\hline SANTANDER & $\stackrel{\circ}{\mp}$ & 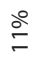 & $\stackrel{\circ}{\circ}$ & ๙े & ஓ̊ & 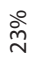 & ஓे & ๙̊ & $\stackrel{\circ}{\mp}$ & $\stackrel{\dot{m}}{m}$ & 웅 \\
\hline HSBC & ஓे & ஓे & 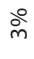 & ஃั & ठ̊ & $\stackrel{m}{\circ}$ & ڤे & คำ & ஓे & $\stackrel{\overbrace =}{\llcorner}$ & $\stackrel{n}{m}$ \\
\hline $\begin{array}{l}\text { Subtotal de Bancos Privados } \\
\text { Estrangeiros }\end{array}$ & $\stackrel{\stackrel{\circ}{\longleftarrow}}{-}$ & $\stackrel{\stackrel{\circ}{+}}{\frac{9}{+}}$ & $\stackrel{\stackrel{\circ}{+}}{\stackrel{2}{+}}$ & ஓ̊ & ๑̊ & ํํำ & ํำ & 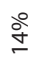 & ஓ̊ & के & $\stackrel{n}{\pi}$ \\
\hline $\begin{array}{l}\text { Subtotal dos Top } 6 \text { Bancos } \\
\text { Comerciais }\end{array}$ & $\frac{\circ}{\infty}$ & ㅇํํ & 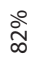 & 商 & $\stackrel{\circ}{\aleph_{\infty}^{\circ}}$ & 웃 & $\frac{\circ}{\infty}$ & $\stackrel{0}{\infty}$ & $\frac{\circ}{\sigma}$ & & \\
\hline $\begin{array}{l}\text { Total Consolidado Bancario I ( } 100 \\
\text { Instituicoes ) }\end{array}$ & ஓ̊̊ & ஓे & ஓे & ஓे & ஓ̊ํㅇ & ஓे & ஓे & ஓे & ஓे & & \\
\hline $\begin{array}{l}\text { \% de Participação Consolidado } \\
\text { Bancario I }\end{array}$ & $\stackrel{\infty}{\infty}$ & 요 & $\infty$ & ন & $\hat{a}$ & $\underset{\infty}{\infty}$ & $\stackrel{n}{n}$ & ब & 으 & & \\
\hline $\begin{array}{l}\text { \% Top } 6 \text { no Sistema Financeiro } \\
\text { Nacional }\end{array}$ & ஓे & $\stackrel{\circ}{\circ}$ & $\stackrel{\circ}{\hat{0}}$ & $\frac{\circ}{\infty}$ & $\frac{\circ}{\infty}$ & ڤે & ठ̊ㅇㅇ & $\underset{\infty}{\stackrel{0}{\infty}}$ & $\frac{\circ}{\sigma}$ & & \\
\hline
\end{tabular}

Fonte: Sisbacen - Banco Central do Brasil (elaboração do autor FNC)

Na Tabela 2, o destaque é a elevação substantivamente maior do Resultado Bruto de Intermediação Financeira dos bancos públicos (de $26 \%$ para $38 \%$ ) face à queda dos bancos privados nacionais (de $37 \%$ para $25 \%$ ). E suas despesas pouco subiram. 
Tabela 2 - 6 Maiores Bancos e o Consolidado do Sistema Financeiro Nacional

\begin{tabular}{|c|c|c|c|c|c|}
\hline Instituições & $\begin{array}{l}\text { Resultado } \\
\text { Bruto IF }\end{array}$ & $\begin{array}{l}\text { Outras } \\
\text { Receitas }\end{array}$ & $\begin{array}{l}\text { Rendas } \\
\text { de Tarifas }\end{array}$ & \multicolumn{2}{|c|}{$\begin{array}{l}\text { Outras Despesas } \\
\text { Operacionais }\end{array}$} \\
\hline & & & & $\begin{array}{l}\text { Despesas de } \\
\text { Pessoal }\end{array}$ & $\begin{array}{l}\text { Outras } \\
\text { Desp. } \\
\text { Adm. }\end{array}$ \\
\hline
\end{tabular}

Data-base: Dezembro/2014

\begin{tabular}{|c|c|c|c|c|c|}
\hline BANCO DO BRASIL & $19 \%$ & $19 \%$ & $20 \%$ & $21 \%$ & $18 \%$ \\
\hline CAIXA ECONOMICA FEDERAL & $18 \%$ & $22 \%$ & $10 \%$ & $20 \%$ & $11 \%$ \\
\hline Subtotal de Bancos Públicos & $38 \%$ & $41 \%$ & $31 \%$ & $42 \%$ & $30 \%$ \\
\hline ITAU & $15 \%$ & $19 \%$ & $26 \%$ & $14 \%$ & $18 \%$ \\
\hline BRADESCO & $10 \%$ & $12 \%$ & $20 \%$ & $14 \%$ & $15 \%$ \\
\hline $\begin{array}{l}\text { Subtotal de Bancos Privados } \\
\text { Nacionais }\end{array}$ & $25 \%$ & $31 \%$ & $46 \%$ & $28 \%$ & $33 \%$ \\
\hline SANTANDER & $13 \%$ & $11 \%$ & $9 \%$ & $7 \%$ & $14 \%$ \\
\hline $\mathrm{HSBC}$ & $3 \%$ & $2 \%$ & $5 \%$ & $5 \%$ & $5 \%$ \\
\hline $\begin{array}{l}\text { Subtotal de Bancos Privados } \\
\text { Estrangeiros }\end{array}$ & $16 \%$ & $12 \%$ & $13 \%$ & $12 \%$ & $19 \%$ \\
\hline $\begin{array}{l}\text { Subtotal dos Top } 6 \text { Bancos } \\
\text { Comerciais }\end{array}$ & $80 \%$ & $84 \%$ & $90 \%$ & $81 \%$ & $82 \%$ \\
\hline $\begin{array}{l}\text { Total Consolidado Bancário I } \\
\text { (96 Instituições) }\end{array}$ & $100 \%$ & $100 \%$ & $100 \%$ & $100 \%$ & $100 \%$ \\
\hline $\begin{array}{l}\text { \% de Participação } \\
\text { Consolidado Bancário I }\end{array}$ & 77,9 & 93,8 & 94,2 & 92,1 & 90 \\
\hline $\begin{array}{l}\text { \% Top } 6 \text { no Sistema } \\
\text { Financeiro Nacional (1565 IF) }\end{array}$ & $72 \%$ & $77 \%$ & $82 \%$ & $77 \%$ & $73 \%$ \\
\hline
\end{tabular}

Data-base: Dezembro/2009

\begin{tabular}{|c|c|c|c|c|c|}
\hline BANCO DO BRASIL & $17 \%$ & $20 \%$ & $25 \%$ & $23 \%$ & $16 \%$ \\
\hline CAIXA ECONOMICA FEDERAL & $9 \%$ & $18 \%$ & $6 \%$ & $18 \%$ & $9 \%$ \\
\hline Subtotal de Bancos Públicos & $26 \%$ & $38 \%$ & $31 \%$ & $41 \%$ & $25 \%$ \\
\hline ITAU & $23 \%$ & $19 \%$ & $20 \%$ & $16 \%$ & $19 \%$ \\
\hline BRADESCO & $14 \%$ & $12 \%$ & $16 \%$ & $13 \%$ & $14 \%$ \\
\hline $\begin{array}{l}\text { Subtotal de Bancos Privados } \\
\text { Nacionais }\end{array}$ & $37 \%$ & $31 \%$ & $36 \%$ & $29 \%$ & $33 \%$ \\
\hline SANTANDER & $13 \%$ & $10 \%$ & $15 \%$ & $9 \%$ & $16 \%$ \\
\hline HSBC & $4 \%$ & $3 \%$ & $4 \%$ & $3 \%$ & $5 \%$ \\
\hline $\begin{array}{l}\text { Subtotal de Bancos Privados } \\
\text { Estrangeiros }\end{array}$ & $17 \%$ & $13 \%$ & $19 \%$ & $13 \%$ & $22 \%$ \\
\hline $\begin{array}{l}\text { Subtotal dos Top } 6 \text { Bancos } \\
\text { Comerciais }\end{array}$ & $80 \%$ & $82 \%$ & $86 \%$ & $83 \%$ & $79 \%$ \\
\hline $\begin{array}{l}\text { Total Consolidado Bancario I } \\
\text { ( } 100 \text { Instituicoes ) }\end{array}$ & $100 \%$ & $100 \%$ & $100 \%$ & $100 \%$ & $100 \%$ \\
\hline $\begin{array}{l}\text { \% de Participação } \\
\text { Consolidado Bancario I }\end{array}$ & 90 & 94 & 95 & 93 & 92 \\
\hline $\begin{array}{l}\% \text { Top } 6 \text { no Sistema } \\
\text { Financeiro Nacional }\end{array}$ & $72 \%$ & $77 \%$ & $82 \%$ & $77 \%$ & $73 \%$ \\
\hline
\end{tabular}

Fonte: Sisbacen - Banco Central do Brasil (elaboração do autor FNC) 
Na Tabela 3, observa-se que todas as carteiras em relação aos ativos se elevaram, enquanto mudou a composição passiva dos bancos públicos, provavelmente com maior repasse de fundos sociais como o FGTS. Considerando-se apenas o $4^{\circ}$. Trimestre, houve queda relativa da rentabilidade patrimonial especialmente do BB e do HSBC. Quanto ao ROA (Return On Asset), caíram as lucratividades dos bancos públicos, efeito de sua expansão com a diminuição das taxas de juros, seja da Selic, seja de empréstimos. Destaca-se também a maior alavancagem financeira da Caixa, em função de sua menor capitalização, em relação aos demais bancos. Embora tenha maior 'número de funcionários por agência' - na realidade, executando políticas públicas na Matriz em Brasília -, a Caixa conseguiu cobertura das despesas de pessoal com receita de prestação de serviços com 91\% em 2009 e 84\% em 2014. Seu Índice de Eficiência (relação entre despesas e receitas) permaneceu em torno de $75 \%$, enquanto o do Banco do Brasil deteriorou-se, pois se elevou de $66 \%$ para $87 \%$. Piora significativa em eficiência também tiveram o Itaú (de 53\% para 74\%) e o Bradesco (de 62\% para $105 \%$ ), mas o caso mais gritante é o do estrangeiro HSBC (de $80 \%$ para $150 \%$ ), ou seja, foi falseado mais uma vez o mito da eficiência dos estrangeiros.

\section{Tabela 3 - 6 Maiores Bancos e o Consolidado do Sistema Financeiro Nacional}

\begin{tabular}{|c|c|c|c|c|c|c|c|c|c|c|}
\hline 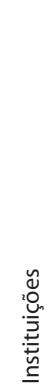 & 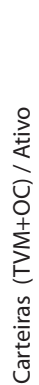 & 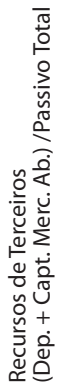 & 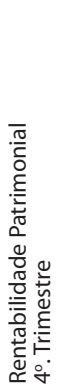 & 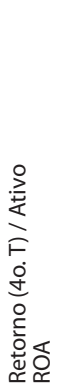 & 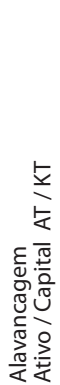 & 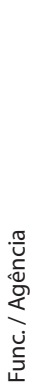 & 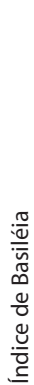 & 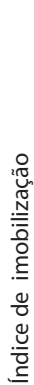 & 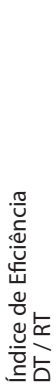 & 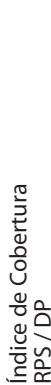 \\
\hline
\end{tabular}

Data-base: Dezembro/2014

\begin{tabular}{l|r|r|r|r|r|r|r|r|r|r}
\hline BANCO DO BRASIL & $58 \%$ & $59 \%$ & $8 \%$ & $0,4 \%$ & 8,3 & & 16,1 & 22,2 & $-87 \%$ & $-73 \%$ \\
\hline $\begin{array}{l}\text { CAIXA ECONOMICA } \\
\text { FEDERAL }\end{array}$ & $72 \%$ & $56 \%$ & $14 \%$ & $0,3 \%$ & 12,5 & & 16,1 & 14,4 & $-75 \%$ & $-84 \%$ \\
\hline $\begin{array}{l}\text { Subtotal de Bancos } \\
\text { Públicos }\end{array}$ & $64 \%$ & $57 \%$ & $10 \%$ & $0,4 \%$ & 9,7 & & & & $-81 \%$ & $-79 \%$ \\
\hline $\begin{array}{l}\text { ITAU } \\
\text { BRADESCO }\end{array}$ & $52 \%$ & $58 \%$ & $10 \%$ & $0,9 \%$ & 5,6 & & 16,9 & 49,1 & $-74 \%$ & $-113 \%$ \\
\hline $\begin{array}{l}\text { Subtotal de Bancos } \\
\text { Privados Nacionais }\end{array}$ & $54 \%$ & $59 \%$ & $10 \%$ & $0,9 \%$ & 5,6 & & & & $-87 \%$ & $-91 \%$ \\
\hline SANTANDER & $57 \%$ & $44 \%$ & $2 \%$ & $0,2 \%$ & 5,1 & & 17,5 & 29,4 & $-78 \%$ & $-118 \%$ \\
\hline HSBC & $51 \%$ & $38 \%$ & $-5 \%$ & $-0,3 \%$ & 9,2 & & 13,1 & 25,0 & $-150 \%$ & $-29 \%$ \\
\hline
\end{tabular}


Tabela 3 - 6 Maiores Bancos e o Consolidado do Sistema Financeiro Nacional

\begin{tabular}{|c|c|c|c|c|c|c|c|c|c|c|}
\hline 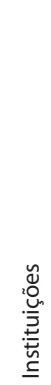 & 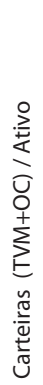 & 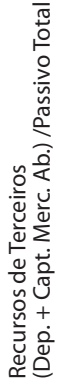 & 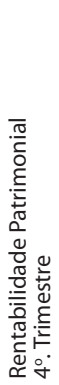 & 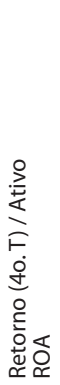 & 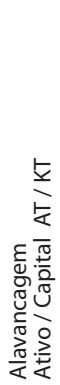 & 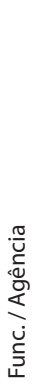 & 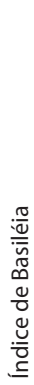 & 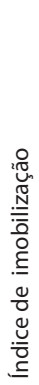 & 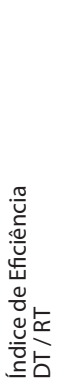 & 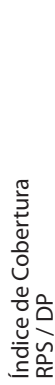 \\
\hline
\end{tabular}

Data-base: Dezembro/2014

\begin{tabular}{|c|c|c|c|c|c|c|c|c|c|c|}
\hline $\begin{array}{l}\text { Subtotal de Bancos } \\
\text { Privados Estrangeiros }\end{array}$ & $56 \%$ & $42 \%$ & $1 \%$ & $0,1 \%$ & 5,7 & & & & $-91 \%$ & $-84 \%$ \\
\hline $\begin{array}{l}\text { Subtotal dos Top } 6 \\
\text { Bancos Comerciais }\end{array}$ & $59 \%$ & $56 \%$ & $8 \%$ & $0,6 \%$ & 7,0 & & & & $-85 \%$ & $-83 \%$ \\
\hline $\begin{array}{l}\text { Total Consolidado } \\
\text { Bancário I (96 } \\
\text { Instituições) }\end{array}$ & $59 \%$ & $53 \%$ & $7 \%$ & $0,5 \%$ & 6,5 & & & & $-87 \%$ & $-80 \%$ \\
\hline $\begin{array}{l}\text { Total do Sistema } \\
\text { Financeiro Nacional } \\
\text { (1565 IF) }\end{array}$ & $58 \%$ & $46 \%$ & $7 \%$ & $0,6 \%$ & & & & & $-81 \%$ & $-79 \%$ \\
\hline \multicolumn{5}{|c|}{ Data-base: Dezembro/2009 } & 6,3 & & & & & \\
\hline BANCO DO BRASIL & $56 \%$ & $72 \%$ & $17 \%$ & $0,9 \%$ & & 25 & 14,0 & 14,6 & $-66 \%$ & $-79 \%$ \\
\hline $\begin{array}{l}\text { CAIXA ECONOMICA } \\
\text { FEDERAL }\end{array}$ & $71 \%$ & $72 \%$ & $14 \%$ & $0,5 \%$ & & 51 & 17,5 & 16,6 & $-74 \%$ & $-91 \%$ \\
\hline $\begin{array}{l}\text { Subtotal de Bancos } \\
\text { Públicos }\end{array}$ & $61 \%$ & $72 \%$ & $16 \%$ & $0,8 \%$ & & 33 & & & $-69 \%$ & $-84 \%$ \\
\hline ITAU & $43 \%$ & $57 \%$ & $11 \%$ & $0,9 \%$ & & 23 & 17,0 & 32,9 & $-53 \%$ & $-105 \%$ \\
\hline BRADESCO & $47 \%$ & $65 \%$ & $10 \%$ & $0,9 \%$ & & 23 & 17,8 & 45,7 & $-62 \%$ & $-82 \%$ \\
\hline $\begin{array}{l}\text { Subtotal de Bancos } \\
\text { Privados Nacionais }\end{array}$ & $45 \%$ & $61 \%$ & $10 \%$ & $0,9 \%$ & & 23 & & & $-56 \%$ & $-95 \%$ \\
\hline SANTANDER & $53 \%$ & $44 \%$ & $1 \%$ & $0,2 \%$ & & 22 & 33,4 & 40,0 & $-68 \%$ & $-100 \%$ \\
\hline HSBC & $49 \%$ & $68 \%$ & $6 \%$ & $0,4 \%$ & & 31 & 15,7 & 31,5 & $-80 \%$ & $-79 \%$ \\
\hline $\begin{array}{l}\text { Subtotal de Bancos } \\
\text { Privados Estrangeiros }\end{array}$ & $52 \%$ & $50 \%$ & $2 \%$ & $0,3 \%$ & & 25 & & & $-71 \%$ & $-94 \%$ \\
\hline $\begin{array}{l}\text { Subtotal dos Top } 6 \\
\text { Bancos Comerciais }\end{array}$ & $53 \%$ & $63 \%$ & $9 \%$ & $0,8 \%$ & & 27 & & & $-64 \%$ & $-90 \%$ \\
\hline $\begin{array}{l}\text { Total Consolidado } \\
\text { Bancario I ( } 100 \\
\text { Instituicoes ) }\end{array}$ & $54 \%$ & $61 \%$ & $8 \%$ & $0,8 \%$ & & 28 & & & $-64 \%$ & $-91 \%$ \\
\hline $\begin{array}{l}\text { Total do Sistema } \\
\text { Financeiro Nacional }\end{array}$ & $54 \%$ & $54 \%$ & $9 \%$ & $0,9 \%$ & & 28 & & & $-63 \%$ & $-90 \%$ \\
\hline
\end{tabular}

Fonte: Sisbacen - Banco Central do Brasil (elaboração do autor FNC) 


\section{Modus Operandi e Perspectivas do Sistema Bancário Brasileiro}

O Brasil dos bancos não pode ser apenas o Brasil dos brancos! Esta talvez seja a grande lição da história bancária brasileira: todo banco que se volta, exclusivamente, ao atendimento da 'elite branca' torna sua presença insignificante, para o povo brasileiro, embora o banqueiro possa ser muito bem-sucedido em termos pessoais, principalmente, vendendo seu banco para estrangeiros. Embranquece, enriquece, desaparece... da construção da nação!

Essa foi a história dos bancos estrangeiros, especialmente, a dos norte-americanos aqui. Acompanhando apenas seus clientes, sejam grandes corporações, seja a colônia de imigrantes oriundos de seus países, restringiram-se aos negócios com câmbio, remessas de dinheiro e/ou financiamento do comércio externo. Não atenderam às atividades internas nem ao povo brasileiro. Exceto o Santander, oriundo da Espanha, que adquiriu o Banespa (banco governamental do Estado de São Paulo), os demais bancos estrangeiros têm baixa participação no mercado brasileiro de varejo bancário.

Os grandes bancos brasileiros, pelo contrário, colaram suas estratégias comerciais aos rumos recentes do País. Perceberam a necessidade de investir em automação bancária para atender em massa. Seus gastos em Tecnologia de Informações (TI) representavam $10,4 \%$ de seus gastos totais. Os gastos em tecnologia bancária tornaram-se crescentes de $\mathrm{R} \$$ 12,6 bilhões em 2008 para R\$ 21,6 bilhões em 2014.

Segundo a Pesquisa FEBRABAN de Tecnologia Bancária, no Brasil, gastos com TI das instituições financeiras representavam 18\% da totalidade das indústrias do país em 2014. Era o setor de atividade que mais investia em TI no País, acumulando ao longo do tempo o total de US\$ 59 bilhões. Aquele percentual de investimento estava em linha com os principais países desenvolvidos e emergentes. Do total de US\$351 bilhões gastos em TI na indústria de serviços financeiros, globalmente, em 2014, o Brasil representou US\$11,9 bilhões, equivalente a $\mathrm{R} \$ 27,3$ bilhões.

O acesso popular ao sistema de pagamentos com moeda bancária só se viabilizou pelo avanço tecnológico da indústria bancária brasileira. O barateamento do atendimento através de cartões eletrônicos, devido à automação bancária, possibilitou ampliar o acesso de clientes pobres. Enquanto uma transação na agência custava ao banco US\$ 1,07, no telefone saía por US\$ 0,54, nas máquinas de autoatendimento, US\$ 0,27, no home banking a US\$ 0,15 e na internet por apenas US\$ 0,10. Em média, cada uma da mais de 39 bilhões de transações bancárias, realizadas em 2013, custou R\$ 0,23. Em 2009, o custo médio das 24 bilhões de transações era de R\$ 0,31, ou seja, houve uma queda de $25 \%$ nesse custo.

Segundo a FEBRABAN, existiam 108 milhões de contas correntes ativos em 2014. Comparando-se o número total de CPFs cadastrados $(133,7$ milhões de CPFs com relacionamentos ativos), divulgado pelo CCS (Cadastro de Clientes do Sistema Financeiro Nacional) do BCB, com a População Economicamente Ativa (PEA) brasileira, a 'bancarização' no País elevou-se de 51\% em 2010 a 60\% em 2014. 
Não parecem ser verdadeiros os números da base de clientes divulgados pelos grandes bancos. Somando suas contas correntes (Itaú, 26 milhões; Bradesco, 26,4 milhões; Caixa, 20,8 milhões; Banco do Brasil, 36,1 milhões), atinge-se 109,3 milhões. Porém, somando-se as bases de clientes, só do Bradesco (74,1 milhões), da Caixa (62 milhões) e do BB (56 milhões), ultrapassam 242,5 milhões, ou seja, mais do que toda a população brasileira de 204,5 milhões em julho de 2015.

Os meios de pagamentos eletrônicos são estratégicos para banco, pois quanto mais comum for seu uso por parte dos seus correntistas, menores serão os saques em papel-moeda e maior será o multiplicador monetário. Reter seus depósitos à vista, via fidelização de seus clientes ao uso de cartões e/ou internet banking, passou a ser estratégia fundamental dos bancos. Se a cadeia comercial entre compradores e vendedores se constituir entre os próprios clientes, não haverá vazamento de recursos de seu sistema de fluxos eletrônicos, e o multiplicador monetário torna-se endógeno.

O total de cartões apresenta crescimento importante de 2010 a 2014 (9\% a.a.), estimando-se entre 880 e 910 milhões neste último ano. Os cartões de crédito, débito e lojistas despontam como meio de pagamento altamente utilizado. De forma geral, os gastos em cartão no Brasil estão crescendo ao longo dos últimos anos: de $23 \%$ em 2011 para 31\% do total de gastos em 2014. O Brasil está a frente de países como Suiça, Alemanha, Itália e México no percentual de gastos em cartões face o consumo familiar. No entanto, ainda existe espaço importante a ser capturado por este canal se considerado o uso em países desenvolvidos como 48\% nos Estados Unidos, 51\% no Reino Unido e 56\% no Canadá.

Uma inovação financeira recente é que grandes empresas não-financeiras emitem títulos de dívida direta (debêntures e notas promissórias) com longo prazo de vencimento, cujos lançamentos são operações estruturadas por bancos que oferecem 'garantia firme' de colocação junto aos investidores e/ou na própria carteira de ativos. Bancos emitem como passivos dessas operações as Letras Financeiras (Subordinadas ou não), com dois ou cinco anos para vencimento, que segregam em 'administração de recursos de terceiros', isto é, nos fundos de investimentos. Os investidores desses fundos, devido à baixa taxa de juros de referência, em termos reais, estão agora dispostos a assumir maior risco, diversificando entre o risco privado e o risco soberano, com a finalidade de aumentar o retorno financeiro.

As captações, em geral, têm características de taxas, prazo e liquidez bastante distintas das apresentadas pelos empréstimos concedidos. Ao produzirem esse descasamento entre os fluxos de caixa dos passivos e dos ativos, os bancos expõemse ao risco de variação de taxa de juros. O risco de refinanciamento ocorre também quando capta-se recursos por meio de depósitos a taxas flutuantes (pós), sujeitas a frequentes ajustes, e se empresta com taxas prefixadas (ou vice-versa). O valor de mercado de qualquer ativo é igual aos seus fluxos futuros de caixa descontados, isto é, trazidos para seu valor atual. O aumento da taxa de juros básica eleva a taxa de desconto aplicável a esses fluxos de caixa e reduz o valor de mercado do ativo. 
Somente com o casamento das durações médias de seus ativos e passivos, ou seja, levando em conta o momento exato de ocorrência de fluxos de entrada ou saída de caixa, poderia o banco proteger-se contra o risco de variação de taxa de juros. Como isso não ocorre, na realidade, ele precifica todos os riscos, inclusive o da inadimplência, e os repassa para os devedores adimplentes. 'Os justos (adimplentes) pagam pelos pecadores (inadimplentes)'... E o crédito fica caro.

Outro componente importante dos spreads, que não depende dos bancos, são os impostos diretos e indiretos e demais encargos fiscais e parafiscais, tais como o custo do compulsório, dos subsídios e do direcionamento de crédito. Esses custos no Brasil são mais altos do que a média internacional e, em conjunto, representam cerca de $25 \%$ na composição dos spreads. Já os custos administrativos assumidos pelos bancos, que representam $12 \%$ dos spreads, são outro fator que poderia estar mais controlado pelos bancos, por exemplo, o excessivo custo da publicidade repassado para o devedor. É possível diminuir o custo do crédito no Brasil.

A históriadocréditoruralno Paísérelativamentefácil de seexaminar.Considerando-o deflacionado, ele se elevou de 1969 a 1979, pois foi amplamente subsidiado com custo abaixo da correção monetária. Entretanto, foi parcamente fiscalizado. Houve desvio para compra de terras, elevando a concentração fundiária, e aplicações no mercado financeiro, aumentando a concentração de riqueza. Com a crise final do regime militar e a reestruturação das finanças públicas, inclusive com o fim da Conta de Movimento entre o Banco do Brasil e o Banco Central do Brasil, ele declinou até o primeiro ano do segundo mandato do Governo FHC. Em aparente paradoxo, o PIB agrícola se elevou durante todo esse período de queda, demonstrando que não havia correlação entre as duas séries - e muito menos causalidade.

As fontes de recursos para o crédito rural se alteraram. Os recursos obrigatórios (alíquota de $34 \%$ dos depósitos a vista com remuneração de 5,5\% aa) que atingiam cerca da metade entre 2006 e 2011, em 2012 baixaram para 34\% em contrapartida da alta da participação dos depósitos de poupança rural (de 18,7\% para 31,8\%) no mesmo período. Fundos constitucionais (FCO, FNE, FINOR) giraram em torno de 8\%, enquanto o BNDES apoia, crescentemente, atingindo 9,9\%. O fato é que pouco se usa de recursos livres para financiar o agronegócio - menos de 5\% - em que pese o Brasil ter se tornado 'o celeiro do mundo'. Bancos privados só emprestam obrigados.

No Brasil, o subsídio está, basicamente, no crédito agrícola. Este possui taxa de juros não só abaixo da taxa de referência do mercado de dinheiro, como também seu custo chega a ser inferior às variações do índice geral de preços. Dessa forma, há a tradição histórica dos produtores adotarem a 'regra do terço' em seus financiamentos: $1 / 3$ com recursos próprios, $1 / 3$ em crédito comercial dos fornecedores de insumos e maquinarias e 1/3 em crédito bancário.

O subsídio agrícola ao crédito rural no Brasil é relativamente diminuto face às experiências de outros países, sendo equivalente de 3 a $4 \%$ da renda agrícola. Nos 
Estados Unidos, atinge 18\%. Na Europa, chega a 34\% dessa renda. Lá o Estado chega a subsidiar até $90 \%$ não é no crédito, mas sim no prêmio do seguro rural.

A adoção de política preventiva, seja via seguro rural, seja via instrumentos de hedge no mercado de derivativos, para a agrobusiness exportador, seria o caminho para se evitar os recorrentes perdões das dívidas propostos pela 'bancada ruralista'. Em dezembro de 2003, foi implantada nova legislação referente a esse seguro, cujo objetivo principal é garantir $70 \%$ da renda em caso de sinistro climático. O Banco do Brasil já condiciona o financiamento de custeio à aquisição do seguro.

O governo brasileiro pretende adotar mecanismos capazes de assegurar a convergência entre o valor do prêmio que o produtor pode pagar e o que a seguradora julga economicamente viável. Assim, os riscos climáticos e sanitários seriam mitigados com o seguro rural e os riscos de mercado, com o mercado formal de derivativos agropecuários em operações de hedge. As transações com derivativos envolveriam instrumentos contratuais de venda antecipada e proteção contra variações cambiais. Tratar-se-ia de transição histórica: da Economia de Endividamento, via BB, para Economia de Mercado de Capitais, via seguradoras ou BM\&F.

Também a história do financiamento imobiliário no Brasil pode ser sintetizada. No final do regime militar (1979-1982), com a prefixação da correção monetária e o choque cambial (maxidesvalorização da moeda nacional) e consequente choque inflacionário, sob o comando do Delfim Netto, provocou-se, inicialmente, o aumento da contratação, e, posteriormente, a inadimplência dos mutuários. O período 1983-1986 foi ‘a crise do sub-prime brasileira', inclusive com a quebra do BNH e a criação do FCVS (Fundo de Compensação da Variação Salarial), dívida pública que só será resgatada em 2027. A gestão da massa de inadimplência manteve-se até 2001 (com sua transferência para a EMGEA) sem expansão significativa do crédito imobiliário, exceto a derivada do 'Margaridaço', a alta artificial da concessão de crédito habitacional sem avaliação de risco, realizada em 1991, por imposição autoritária da Ministra da Habitação do Governo Collor, Margarida Procópio. A sociedade brasileira ficou, praticamente, 20 anos (1983-2003) sem acesso fácil ao crédito imobiliário.

A Caixa não concedia crédito imobiliário com recursos dos depósitos de poupança desde 1992, pois estava 'sobreaplicada' acima de 65\% da exigibilidade. A partir de 2005, sua alta administração tomou a decisão de transferir esses recursos, até então aplicados em Tesouraria, de volta ao financiamento do SBPE. A VIURB, Vice-presidência de Desenvolvimento Urbano, foi mudada em abril de 2005. Desde então, houve um re-evolução no crédito imobiliário no Brasil, acentuada pelo programa social MCMV que contratou, até 2013 , 3.316.430 unidades habitacionais, 1.857 .815 sendo construídas e 1.614.820 já entregues.

O crédito imobiliário tornou-se o que crescia mais rapidamente entre todas as modalidades de financiamentos. Sua participação no PIB, mesmo subestimada pelo Banco Central, em 2013, atingiu 8,2\%, certamente alcançará 12\% até o final da década. Porém, será ainda um patamar bem inferior ao dos países que passaram por 'bolha 
imobiliária', como Estados Unidos (68,8\%) e Espanha. Nesses, fizeram securitização do crédito imobiliário.

Há vantagens de emissão de Certificados de Recebíveis Imobiliários (CRI):

1. realização de lucro antecipada;

2. redução dos riscos pela transferência para companhias securitizadoras e, daí, para investidores institucionais (fundos de pensão); e

3. ganho de liquidez com a maior rotação de capital para a concessão de novo crédito.

Finalmente, vale citar a área estratégica de negócio bancário relacionada à mobilidade social, pois a Classe Média (C) passou de 38\%, em 2002, para 55,3\%, em 2012, e as Classes AB passaram de 7,4\% para 11,7\%. Cerca de 104 milhões de pessoas pertencem a Classe Média, cujo limite inferior de renda é $\mathrm{R} \$ 291$ per capita. Ela tem hoje 37 milhões de pessoas a mais do que tinha há uma década.

Com isso, o País passou a ter cerca de 3,5 milhões de vendas anuais de automóveis (e se aproximou de 2 milhões de vendas anuais de motos). $\mathrm{O}$ índice de habitantes por veículo $(5,7)$ ainda é relativamente alto. O financiamento a veículo está estacionado em torno de $7 \%$ do saldo total de crédito. O País tem o $4^{\circ}$. maior mercado de automóveis do mundo em vendas, embora seja o $7^{\circ}$. maior produtor. Da sua frota de 40,8 milhões de veículos somente $30 \%$ é segurada. Portanto, tanto em financiamento, como em vendas de seguros, esta área automobilística possui uma perspectiva de negócios bancários promissora no Brasil.

Cabe, por fim, registrar que embora o País tivesse o $7^{\circ}$. maior PIB no ranking mundial de 2013, na relação prêmios de seguro / PIB (3,7\%) ele ficou em 13․ lugar com apenas $1,88 \%$ do mercado global. Havia apenas $10 \%$ das residências seguradas, planos de saúde cobriam $24 \%$ da população e planos odontológicos, $8 \%$. Como 29,7\% será a parcela de idosos na população brasileira, em 2050, haverá imensa janela de oportunidade histórica aberta para os negócios bancários nas áreas de seguros, previdência complementar e crédito consignado para aposentados. $\mathrm{O}$ crédito educativo, assumido como consignado, isto é, descontado na folha de pagamento no primeiro emprego do graduado, será outra oportunidade.

Em breve, o País se tornará exportador de petróleo extraído sob o pré-sal. Seu Fundo Social de Riqueza Soberana investirá 75\% em Educação e 25\% em Saúde. Provavelmente, a qualidade de vida do povo brasileiro melhorará muito. E junto com ela, a perspectiva de negócios bancários para todos os bancos, inclusive os públicos que contribuem para esse desenvolvimento socioeconômico. 


\section{Conclusão}

Constatamos uma série de virtudes dos bancos públicos brasileiros:

1. corrigir falhas de mercado: realocar recursos para regiões (Norte/Nordeste) e/ou setores (agricultura, habitação, infraestrutura) prioritários, mas não tão lucrativos e atraentes para iniciativas particulares;

2. captar recursos no mercado, complementando recursos fiscais escassos;

3. carregar títulos de dívida pública, dando ao governo certa autonomia em relação aos bancos privados;

4. obter lucros para pagar dividendos ao Tesouro Nacional, elevando o superávit primário;

5. compensar eventuais perdas, no cumprimento de missão social, com ganhos na ação comercial;

6. executar políticas públicas, por exemplo, com correspondentes bancários, crédito consignado, contas simplificadas, programas de habitação de interesse social, programa de apoio à agricultura familiar, etc., usando fundos sociais, ou seja, evitando lucros privados com dinheiro público.

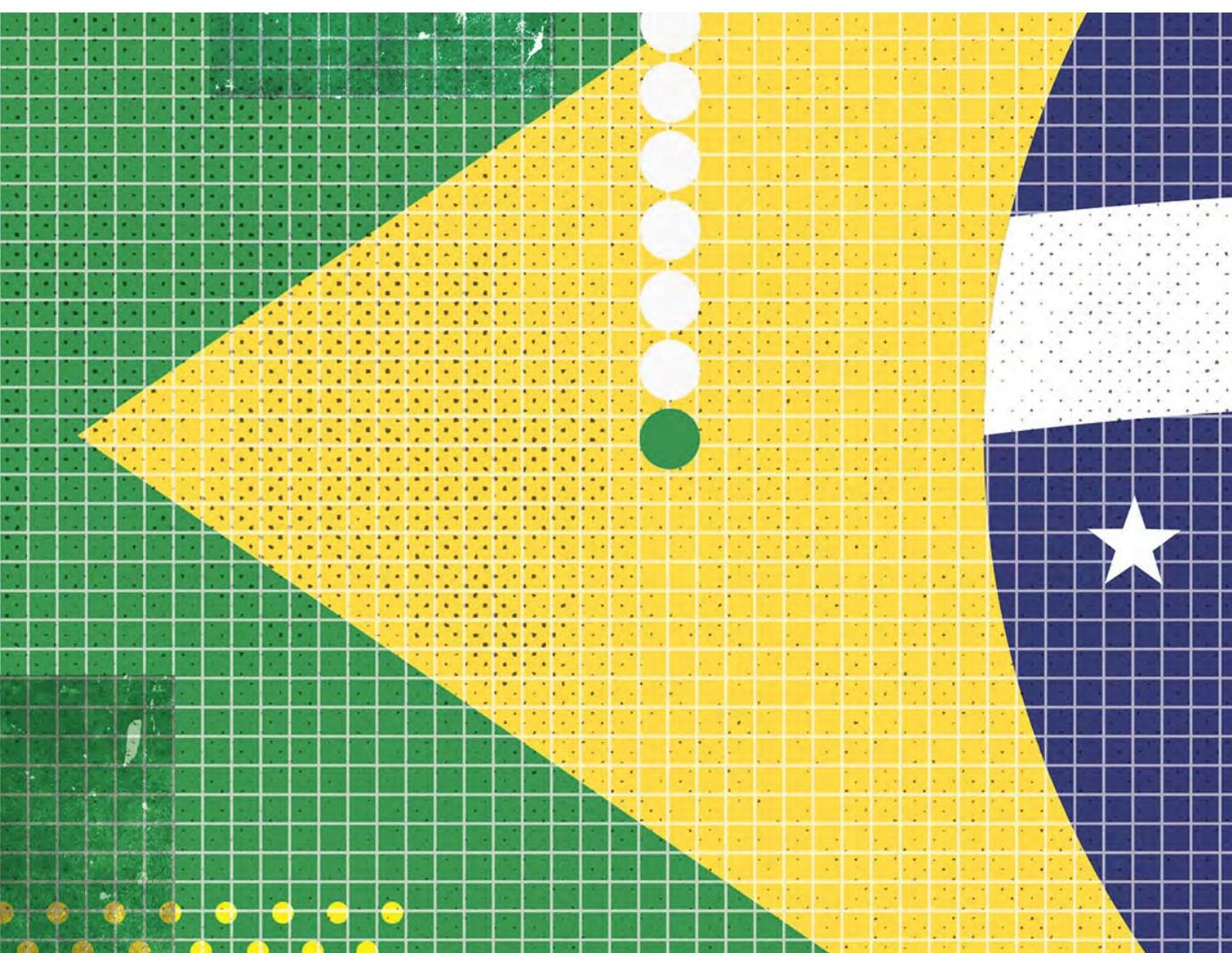


Essas virtudes não escondem os defeitos contumazes nas direções dos bancos públicos:

1. corporativismo, quando há a defesa exclusiva dos próprios interesses profissionais por parte da categoria funcional, ou seja, espírito de corpo ou de grupo e não espírito público;

2. apadrinhamento político, isto é, o favorecimento ou a proteção de alguns servidores ou a indicação de dirigentes por parte de parlamentares, governadores, ministros, etc.;

3. ineficiência, embora não seja problema exclusivo, eles são muito carentes da característica de conseguir o melhor rendimento com o mínimo de erros e/ou de dispêndio de energia, tempo, dinheiro ou meios;

4. a lei da licitação provoca a 'síndrome do TCU' entre seus servidores, levando à fuga da responsabilidade individual para a diluição das responsabilidades em inúmeros comitês e pareceres e provocando a morosidade das decisões;

5. a exigência de concursos públicos, que provoca a dificuldade de contratar especialistas com nível de excelência e qualificação profissional da concorrência;

6. o excesso de 'mercadologia', isto é, ideologia mimética em relação aos concorrentes privados, inclusive gastando excessivamente em marketing convencional.

Concluo sugerindo que talvez a solução para o problema de interferência política na escolha de dirigentes nos bancos públicos, inclusive para os do Banco Central do Brasil, esteja na exigência, para todos os candidatos, de formação em uma Escola Superior de Administração Bancária (ESAB), ou seja, uma pós-graduação de excelência à semelhança do Instituto Rio Branco do Itamaraty ou da ESAF - Escola Superior de Administração Fazendária. Se tanto servidores públicos concursados quanto profissionais interessados na carreira fossem obrigados a ter cumprido essa obrigação, previamente a qualquer indicação governamental, a qualificação seria superior. 


\section{Bibliografia}

ANDRADE, ROGÉRIO PEREIRA DE; DEOS, SIMONE DE (2009). A trajetória do Banco do Brasil no período recente, 2001-2006: banco público ou banco estatal 'privado'? Revista de Economia Contemporânea, Abr 2009, vol.13, no.1, p.47-79.

ARAÚJO, ELDER LINTON ALVES DE. Os bancos públicos frente ao processo de privatizaçãoe internacionalização bancária no Brasil nos anos 90. Campinas, Dissertação de Mestrado pelo IEUNICAMP, $2001.90 \mathrm{p}$.

BANCO DO BRASIL. História do Banco do Brasil. Distrito Federal, Coordenadoria de Comunicação Social do Gabinete da Presidência e Agência Brasileira de Comunicações: Ítalo Bianchi Publicitários Associados Ltda., 1987.

COSTA, FERNANDO NOGUEIRA DA. 'Contra-Racionamento de crédito: do raro e caro ao farto e barato'. In: MENDONÇA, A. R. R. \& ANDRADE, R. P. (org.). Regulação Bancária e Dinâmica Financeira: Evolução e Perspectivas a partir dos Acordos de Basiléia. Campinas, Editora do IEUNICAMP, 2006. pp. 445-476.

COSTA, FERNANDO NOGUEIRA DA. Bancos e Crédito no Brasil: 1945-2007. História e Economia. São Paulo, Revista da BBS, v. 4, p. 249-276, 2008.

COSTA, FERNANDO NOGUEIRA DA. Agenda Neoliberal: Privatizar Bancos Públicos. Revista de Economia da Mackenzie. São Paulo, v. 7, p. 4-30, 2009.

COSTA, FERNANDO NOGUEIRA DA. Banco do Brasil 200 Anos: 1964-2008. História do Banco do Brasil. Livro 2. Belo Horizonte: Diretoria de Marketing e Comunicação do Banco do Brasil - Del Rey, Fazenda Comunicação \& Marketing, 2010. 224 páginas.

COSTA, FERNANDO NOGUEIRA DA (2012). Brasil dos Bancos. São Paulo, EDUSP.

COSTA, FERNANDO NOGUEIRA DA. Capitalismo de Estado Neocorporativista. Campinas - SP: Instituto de Economia da UNICAMP, julho de 2012 (Texto de Discussão 207).

COSTA, FERNANDO NOGUEIRA DA e PINTO, GABRIEL MUSSO DE ALMEIDA. Impactos da Pressão para Concorrência Bancária no Mercado de Crédito Brasileiro. Campinas - SP: IE-UNICAMP, fevereiro de 2013 (Texto de Discussão 215).

COSTA, FERNANDO NOGUEIRA DA. Financiamento Interno de Longo Prazo. in Calixtre, A., Biancarelli, A. e Cintra, M. A. M. (ed.). Presente e Futuro do Desenvolvimento Brasileiro. Brasília; IPEA; 2014. Capítulo 8.

DEOS, SIMONE \& MENDONÇA, ANA ROSA R. DE (2010). 'Uma proposta de delimitação conceitual dos bancos públicos'. in Jayme Jr., F.G. ; Crocco, M. (Orgs.) Bancos Públicose Desenvolvimento. Distrito Federal, IPEA; pp. 49-72.

DE PAULA, LUIZ FERNANDO \& OREIRO, JOSÉ LUÍS (org.). Sistema Financeiro: uma Análise do Setor Bancário Brasileiro. Rio de Janeiro, Elsevier-Campus, 2007.

METTENHEIN, KURT. (2010), Para uma Análise Transdisciplinar dos Bancos Públicos Federais na Democracia Brasileira, in Jayme Jr., F.G. ; Crocco, M. (Orgs.). Bancos Públicos e Desenvolvimento. Distrito Federal, IPEA; pp. 105-150.

MONTEBELLO, SILVIA CAMARGO. BB: Banco do Brasil ou do Governo? Dilema Histórico de uma Instituição (1808-1988). SP, Dissertação de Mestrado pela PUC-SP, 1993. 154 p.

REZENDE, FELIPE. Why Does Brazil's Banking Sector Need Public Banks? What Should Bndes Do? The Multidisciplinary Institute for Development and Strategy (MINDS); Discussion Paper No 1; 2015.

RODRIGUES, LEA CARVALHO. Metáforas do Brasil: demissões voluntárias, crise e rupturas do Banco do Brasil. SP, Annablume/FAPESP, 2004. 390 p. 
TORRES FO., ERNANI TEIXEIRA \& COSTA, FERNANDO NOGUEIRA DA. Financiamento de longo prazo no Brasil: um mercado em transformação. Texto para discussão 1843 / Instituto de Pesquisa Econômica Aplicada.- Brasília : Rio de Janeiro : Ipea, junho de 2013. 49 páginas - ISSN 1415-4765 TORRES FILHO, ERNANI TEIXEIRA \& COSTA, FERNANDO NOGUEIRA DA. BNDES $~ O$

Financiamento do Desenvolvimento. Economia \& Sociedade. V. 21. Número Especial, p. 975-1009, dez. 2012.

VIDOTTO, CARLOS AUGUSTO. Banco do Brasil. Crise de uma Empresa Estatal do Setor Financeiro (1964-92), Campinas (SP), Dissertação de Mestrado, IE-Unicamp, 1995. 258 p.

VIDOTTO, CARLOS AUGUSTO. O sistema financeiro brasileiro nos anos 90: um balanço das mudanças estruturais. Campinas, Tese de Doutoramento pelo IE-UNICAMP, 2002.

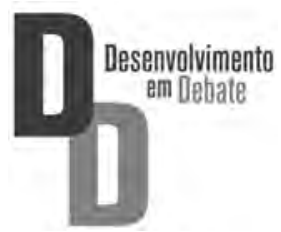

